\title{
Peneplains and tectonics in North-East Greenland after opening of the North-East Atlantic
}

\author{
Johan M. Bonow*1,2,3 (D), Peter Japsen ${ }^{3}$ (D) \\ ${ }^{1}$ Geovisiona AB, Bro, Sweden, ${ }^{2}$ Department of Social and Economic Geography, Uppsala University, Uppsala, Sweden, ${ }^{3}$ Geological Survey of Denmark \\ and Greenland (GEUS), Copenhagen, Denmark.
}

\begin{abstract}
Elevated plateaus with deeply incised valleys characterise elevated, passive continental margins (EPCMs) in all climate zones. These features are, however, a topic of debate regarding when and how the large-scale landscapes formed. We have investigated and mapped the partly glaciated landscape of North-East Greenland $\left(70-78^{\circ} \mathrm{N}\right)$. The area consists of crystalline basement and Palaeozoic-Mesozoic rift basins, capped by Palaeogene basalts that erupted during the northeast Atlantic break-up. Our stratigraphic landscape analysis reveals a typical EPCM dominated by two elevated erosion surfaces, extending $200 \mathrm{~km}$ east-west and $900 \mathrm{~km}$ north-south. The low-relief Upper Planation Surface (UPS; c. 2 km above sea level) cuts across basement and Palaeogene basalts, indicating that it was graded to base level defined by the Atlantic Ocean in post-basalt times and subsequently uplifted. The UPS formed prior to the deposition of mid-Miocene lavas that rest on it, south of the study area. In the interior basement terrains, the Lower Planation Surface (LPS) forms fluvial valley benches at c. $1 \mathrm{~km}$ above sea level, incised below the UPS. The LPS is thus younger than the UPS, which implies that it formed post mid-Miocene. Towards the coast, the valley benches merge to form a coherent surface that defines flat-topped mountains. This shows that the LPS was graded to near sea level and was subsequently uplifted. Hence, both the UPS and the LPS formed as peneplains - erosion surfaces graded to base level. The fluvial valley benches associated with the LPS further indicates that full glacial conditions were only established after the uplift of the LPS in the early Pliocene (c. $5 \mathrm{Ma}$ ). The uplift of the LPS led to re-exposure of a Mesozoic etch surface. We conclude that episodes of late Neogene tectonic uplift shaped the stepped landscape and elevated topography in North-East Greenland.
\end{abstract}

\section{Introduction}

Elevated plateaus (or planation surfaces) that extend over wide areas are characteristic features of elevated, passive, continental margins (EPCM) Uessen 1943; King 1967; Lidmar-Bergström et al. 2000; Japsen et al. 2012a; Green et al. 2013). They occur in all climate zones from the Arctic to tropical and along with Mesozoic and Palaeogene rift systems, along the margins of the Atlantic Ocean from South Africa and Brazil to Norway and Greenland. The formation of these surfaces, and when and how they reached their present elevation, is a topic of debate. Are the elevated plains remnants of pre-rift

\author{
*Correspondence: johan.bonow@ \\ geovisiona.com \\ Received: 20 Aug 2019 \\ Accepted: 06 Aug 2020 \\ Published: 21 Jan 2021
}

Keywords: Cenozoic, denudation chronology, passive margin, stratigraphic landscape analysis, uplift

\section{Abbreviations:}

AFTA: apatite fission-track analysis a.s.I.: above sea level

ASTER GDEM: advanced space-borne thermal emission and reflection radiometer global digital elevation model EPCM: elevated passive continental margins ES: etch surface GLOBE: Global Land One-kilometre Base Elevation

LPS: Lower Planation Surface ODP: Ocean Drilling Program UPS: Upper Planation Surface

GEUS Bulletin is an open access, peerreviewed journal published by the Geological Survey of Denmark and Greenland (GEUS). This article is distributed under a CC-BY 4.0 licence, permitting free redistribution and reproduction for any purpose, even commercial, provided proper citation of the original work is given. Author(s) retain copyright.

Edited by: Catherine Jex (GEUS, Denmark)

Reviewed by: Adrian Hall (Stockholm University, Sweden), Jean-Pierre Peulvast (University of Sorbonne, France)

Funding: See page 30

Competing interests: None declared

Additional files: See page 30 
landscapes that have remained largely unaffected by later processes (Ollier \& Pain 1997)? Did they form during rifting or break-up and remain at high elevation (Gilchrist \& Summerfield 1990; Gallagher et al. 1998; Bishop 2007; Braun 2018)? Did they form by glacial and periglacial processes at high elevation in Arctic regions (Steer et al. 2012; Egholm et al. 2017)? Or were they graded to the base level of the adjacent sea by fluvial erosion long after rifting and break-up, and were subsequently uplifted to their present elevation (Lidmar-Bergström et al. 2000, 2013, 2017; Bonow et al. 2006a, 2006b, 2014; Japsen et al. 2012a, 2019; Green et al. 2013)?

Bonow et al. (2014) used stratigraphic landscape analysis (Lidmar-Bergström et al. 2013, 2017) to identify and map two elevated planation surfaces, the Upper and Lower Planation Surface (UPS and LPS, respectively) in southern-East Greenland $\left(68-71^{\circ} \mathrm{N}\right.$; here referred to as the Blosseville Kyst region, primarily south of Scoresby Sund). The bedrock of Blosseville Kyst is dominated by flood basalts that erupted around the Paleocene-Eocene transition during the break-up of the North-East Atlantic (Larsen et al. 1989; Pedersen et al. 1997; Gaina et al. 2017). As these planation surfaces cut across the Palaeogene basalts as well as the metamorphic basement, Bonow et al. (2014) inferred that they were graded towards the level of the newly formed North-East Atlantic. Consequently, the present elevation of the UPS and the LPS that reach 3 and $2 \mathrm{~km}$

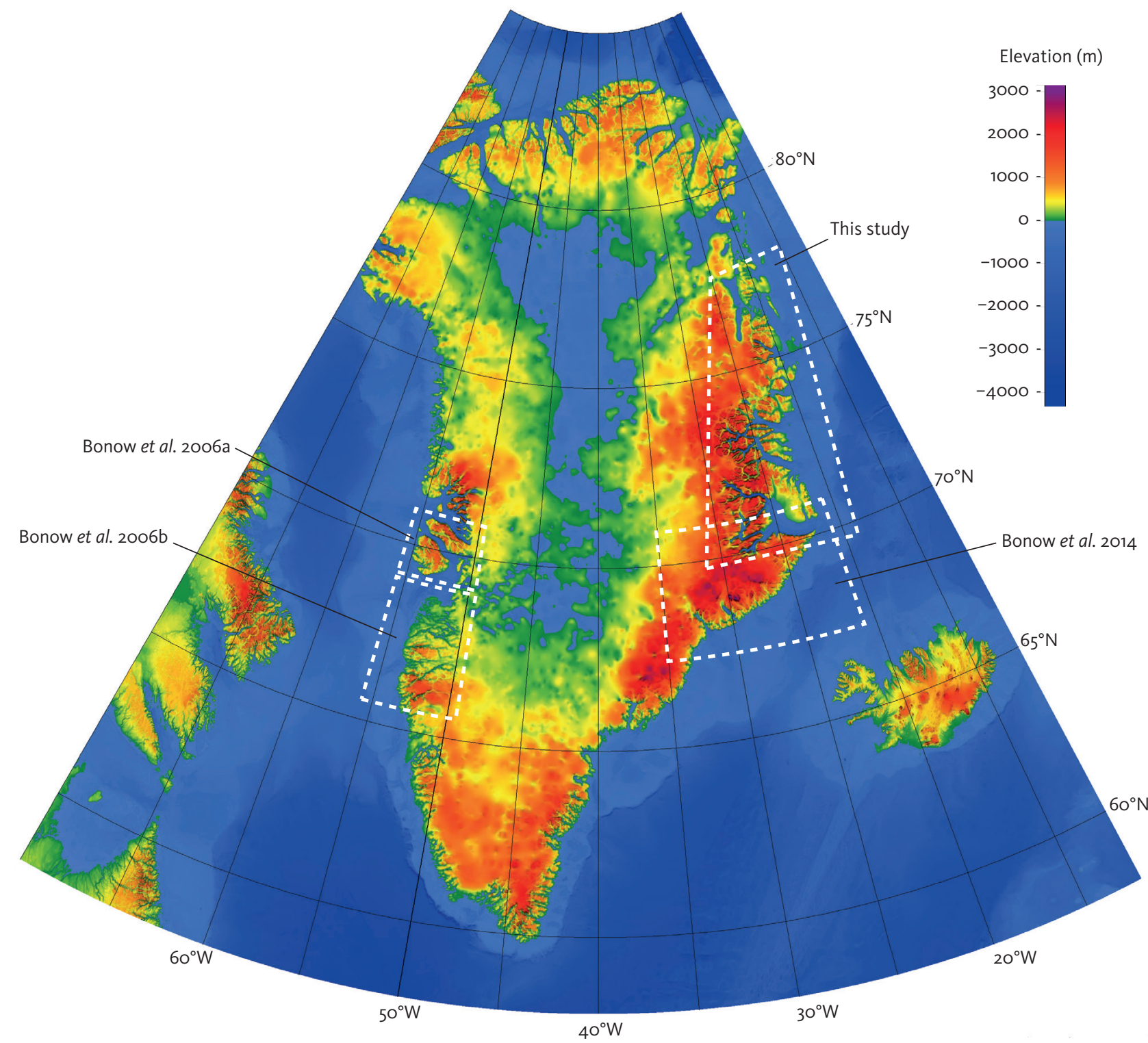

Fig. 1 Bedrock topography of Greenland: Areas investigated by stratigraphic landscape analysis are indicated (Bonow et al. 2006a, 2006b, 2014; and this study). The landscape of East Greenland is generally of higher elevation than West Greenland, where elevated areas are restricted to the coast. The load of the Greenland ice sheet causes up to $850 \mathrm{~m}$ subsidence of the bedrock topography in central Greenland. Peripheral bulging along the margins of Greenland, caused by this ice loading, has a negligible effect on elevation (Medvedev et al. 2013). Elevation data is from Amante \& Eakins (2009). 
above sea level (a.s.I.), respectively, in southern East Greenland, reflect uplift after their formation. Three major phases of uplift and erosion led to the formation and subsequent uplift of these surfaces in late Eocene, late Miocene and early Pliocene as estimated from apatite fission-track analysis (AFTA) data and landscape observations (Japsen et al. 2014). These results are further confirmed by AFTA data from North-East Greenland (Japsen et al. in press).

Here, we continue the work of Bonow et al. (2014) by presenting coherent maps and analyses of the largescale landscape of North-East Greenland, north of Scoresby Sund $\left(70-78^{\circ} \mathrm{N}\right.$; Fig. 1). Whereas the previous study focussed on the region dominated by the Palaeogene basalts, this study investigates the geomorphology along the late Palaeozoic - Mesozoic rift system of East Greenland (Surlyk 1977, 1978, 2003; Parsons et al. 2017). An important question is: does the largescale landscape here mainly contain elements that are inherited from the time of rifting and break-up, or is the landscape instead dominated by younger features? For example, Swift et al. (2008) argued that the first-order topography in North-East Greenland had existed since at least the time of break-up, at c. $55 \mathrm{Ma}$.

We apply the stratigraphic landscape analysis to identify and map planation surfaces in North-East Greenland and produce a relative tectonic event chronology that defines the major phases of denudation and uplift that led to the formation of the present landscape. The results may thus provide further insight into highly debated topics in recent years, including:

1. The origin of elevated plateaus along passive continental margins (Lidmar-Bergström et al. 2000; Japsen et al. 2009, 2012a, 2012b, 2019; Hetzel et al. 2011; Green et al. 2013, 2018; Haider et al. 2013; Calvet et al. 2015; Braun 2018; da Silva et al. 2018; Guillocheau et al. 2018).

2. The development of the margins of the North-East Atlantic Japsen \& Chalmers 2000; Nielsen et al. 2009;
Chalmers et al. 2010; Pedersen et al. 2012; Japsen et al. 2013, 2014; Lidmar-Bergström et al. 2013, 2017; Bonow et al. 2014; Egholm et al. 2017).

3. The role of tectonics for triggering the formation of the Greenland ice sheet (Pedersen \& Egholm 2013; Solgaard et al. 2013; Steinberger et al. 2015; Pérez et al. 2018).

\section{Stratigraphic landscape analysis for mapping erosion surfaces in East Greenland}

In this study, we apply the same technique for mapping erosion surfaces as Bonow et al. (2014), that is, stratigraphic landscape analysis (Green et al. 2013; Lidmar-Bergström et al. 2013). We define an erosion surface graded to base level as a peneplain, in agreement with the original idea of Davis (1899), who stressed the fundamental importance of a base level for the development of an eroding landscape. Thus, we use the term peneplain for any erosion surface graded to base level. Stratigraphic landscape analysis is based on:

1. The relationship between peneplains in crystalline basement and their cover rocks of different ages.

2. The cross-cutting relationships between such re-exposed peneplains and epigene peneplains (peneplains that have never been covered by sedimentary rocks).

3. The occurrence of valleys incised below peneplains (Fig. 2).

Stratigraphic landscape analysis is thus a further development of a long tradition in geomorphology focussed on the study of large-scale landforms that contain information about long-term erosional processes and tectonic events (Davis 1899; Reusch 1901; Ahlmann 1919, 1941; Penck 1924; Baulig 1935;Jessen 1943; King 1967; Brunsden 1993; Ahnert 1998; Godard et al. 2001; Benito-Calvo \& Pérez-González 2007; Peulvast et al. 2009, 2011; Hetzel

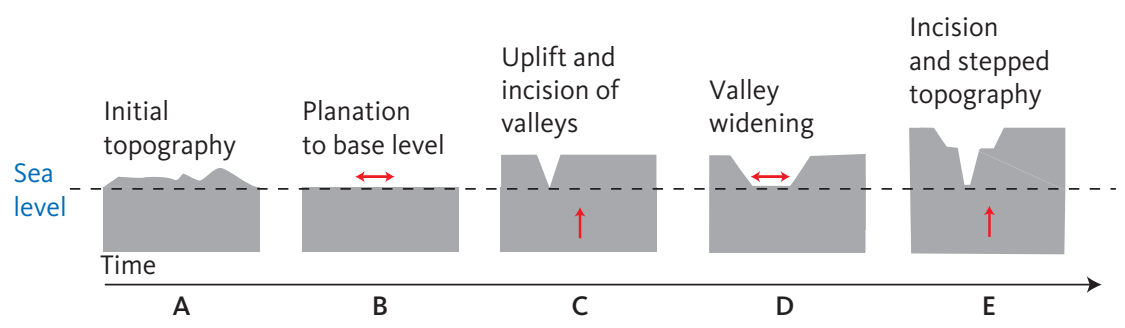

Fig. 2 Conceptual diagram illustrating the formation of peneplains through time: A: Initial topography. B: Formation of a first peneplain by planation of the landscape to base level (sea level) in a tectonically stable environment. C: Tectonic uplift or a significantly lowered base level results in valley incision below the peneplain. D: Erosion continues within the valleys resulting in valley widening and the formation of a second peneplain controlled by the new base level. Erosion primarily affects the older, elevated peneplain along its edges. E: Renewed uplift ends the formation of the second peneplain and valleys again grade the landscape to the new base level. The result is a landscape with distinct steps. At this scale and for the time span considered (c. 10 Myr), the downwearing of the peneplains is negligible (Fu et al. 2019). 
et al. 2011; Haider et al. 2013; Li et al. 2014; Ma et al. 2020). Classical models of landscape development focus on the idea of continuous uplift, interrupted by periods of quiescence (Davis 1899; Baulig 1935; Fairbridge \& Finkl 1980; Benito-Calvo \& Pérez-González 2007). However, stratigraphic landscape analysis emphasises that the relationship between relief in basement and cover rocks provides information about both uplift and subsidence of a region (Lidmar-Bergström et al. 2013).

It is important to understand the relationship between the geology of the rocks into which a surface is eroded and the present appearance and extent of the surface. An extensive erosion surface across resistant rocks (such as crystalline basement) will require a long time to form, but once formed it will persist for a long time in the landscape. On the other hand, an erosion surface that forms across less resistant rocks (such as sediments) will form more quickly, and the surface will be dissected faster than a surface formed in crystalline basement (Simon-Coinçon et al. 1997; Fjellanger \& Etzelmüller 2003; Bonow et al. 2009; Green et al. 2013). Another aspect that must be considered during the mapping of peneplains is the possible complications from structural control in terrains with flat-lying cover rocks, which are common in northeast Brazil (Peulvast \& Bétard 2015) and also in parts of North-East Greenland.

The formation of regional, extensive erosional surfaces is likely to be governed by the common base level to which rivers erode, given time and sufficient tectonic stability. Thus, if an erosion surface loses its contact with the base level to which it formed, it is a palaeosurface, and it will begin to be dissected by incising valleys and the relief will rejuvenate. The valleys will eventually be widened, which results in a new erosion surface graded towards the base level (Ahnert 1998; Bonow 2004; Lidmar-Bergström et al. 2017). Such landscapes will thus be characterised by plateaus in distinct steps and deeply incised valleys (Fig. 2), similar to the landscapes in eastern Australia and southern Norway, the Shillong
Plateau, India and West Greenland (Lidmar-Bergström et al. 2000; Bonow et al. 2006a; Biswas et al. 2007). The parsimonious explanation is that these plateaus are erosion surfaces that were graded to distinct base levels (Japsen et al. 2009). The next parsimonious explanation is that the base levels correspond to sea level at the time of erosion of the surface. Where a study area is known to have been near the sea at the time in question, and the surface is not defined by a resistant level, this is the obvious explanation.

An erosion surface may be buried after its formation and thus, be preserved below its cover. Such buried surfaces can be identified as unconformities in boreholes, on offshore seismic profiles and on exposed sections (e.g. Larsen et al. 1989; Bate 1997; Lassen \& Thybo 2012; Parsons et al. 2017). However, uplift events may lead to re-exposure of previously buried surfaces (Lidmar-Bergström 1989; Bonow 2005; Peulvast et al. 2011). The characteristics of a re-exposed surface (e.g. relative relief outliers and saprolite types) often allow it to be followed along topographical profiles or identified away from its cover. If the re-exposed surface is tilted, its extension may at some point be cut-off by younger erosion that forms a new, more horizontal surface with low-angular unconformity. In such a setting, it can be inferred that the erosion responsible for the formation of the younger surface must have involved both erosion of former cover rocks and of the re-exposed surface (Fig. 3, Lidmar-Bergström et al. 2017).

The cross-cutting relationships between peneplains of different tilts and with different relief and cover provide information about the relative denudation chronology. A relative denudation chronology is a key input to studies of uplift and erosion along a passive margin, similar to other independent datasets, such as evidence from the stratigraphic record and thermochronological data. The chronology provides tectonic information during periods where little or no geological information is otherwise available. Such periods, with little or no

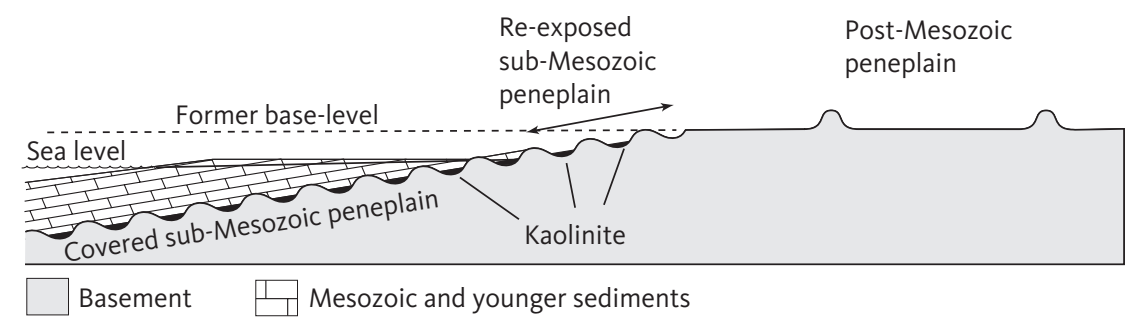

Fig. 3 Relationship between peneplains and cover rocks in southern Sweden: The presence of Mesozoic outliers and remnants of kaolinitic saprolites at a high position in the landscape, demonstrates that Mesozoic cover was once more extensive. The nearhorizontal peneplain cut off the tilted sub-Mesozoic peneplain and is therefore younger. The geological constraints and the appearance of the two surfaces reveal a history of erosion (formation of the sub-Mesozoic peneplain), subsidence and deposition of the Mesozoic strata, followed by tilting and uplift (change from a near-horizontal surface to an inclined surface), erosion (removal of cover and formation of a new peneplain) and a late uplift phase that explains the landscape configuration. Based on Lidmar-Bergström (1982, 1988); Green et al. (2013); Lidmar-Bergström et al. (2013, 2017). 
preserved geological record, often represent a larger timespan than that for which a stratigraphic record exists (e.g. Ager 1973; Green et al. 2013).

\section{Study area}

\subsection{Geologic and tectonic setting}

The bedrock of North-East Greenland consists of Precambrian and Caledonian basement overlain by Palaeozoic, Mesozoic and Cenozoic cover rocks (Fig. 4, Henriksen et al. 2008, 2009). This geological setting is favourable for an analysis of the relationship between basement and cover rocks, because the minimum age of re-exposed basement surfaces can be constrained by the age of the cover rocks, and the maximum age of surfaces that were never covered (epigene surfaces) can be constrained by the age of the cover rocks that they cut across. It is then possible to use such relationships to establish a chronology for the development of palaeosurfaces (e.g. Lidmar-Bergström 1988; Bonow 2005; Lidmar-Bergström et al. 2013).

The Caledonian orogeny lasted from 465 to $400 \mathrm{Ma}$ (Middle Ordovician to early Devonian), and culminated in the collision between Laurentia and Baltica about 420 Ma (latest Silurian; Henriksen 2008). The Caledonian mountains collapsed between 400 and 355 Ma (early Devonian to earliest Carboniferous), and the sediments from the eroding Caledonides were deposited in sedimentary basins parallel to the present coast in central East Greenland (Larsen \& Bengaard 1991; Higgins et al. 2008). The sea transgressed the eroded Caledonian basement in the late Permian (Haller 1971; Surlyk 1990). A series of Carboniferous-Mesozoic rift basins

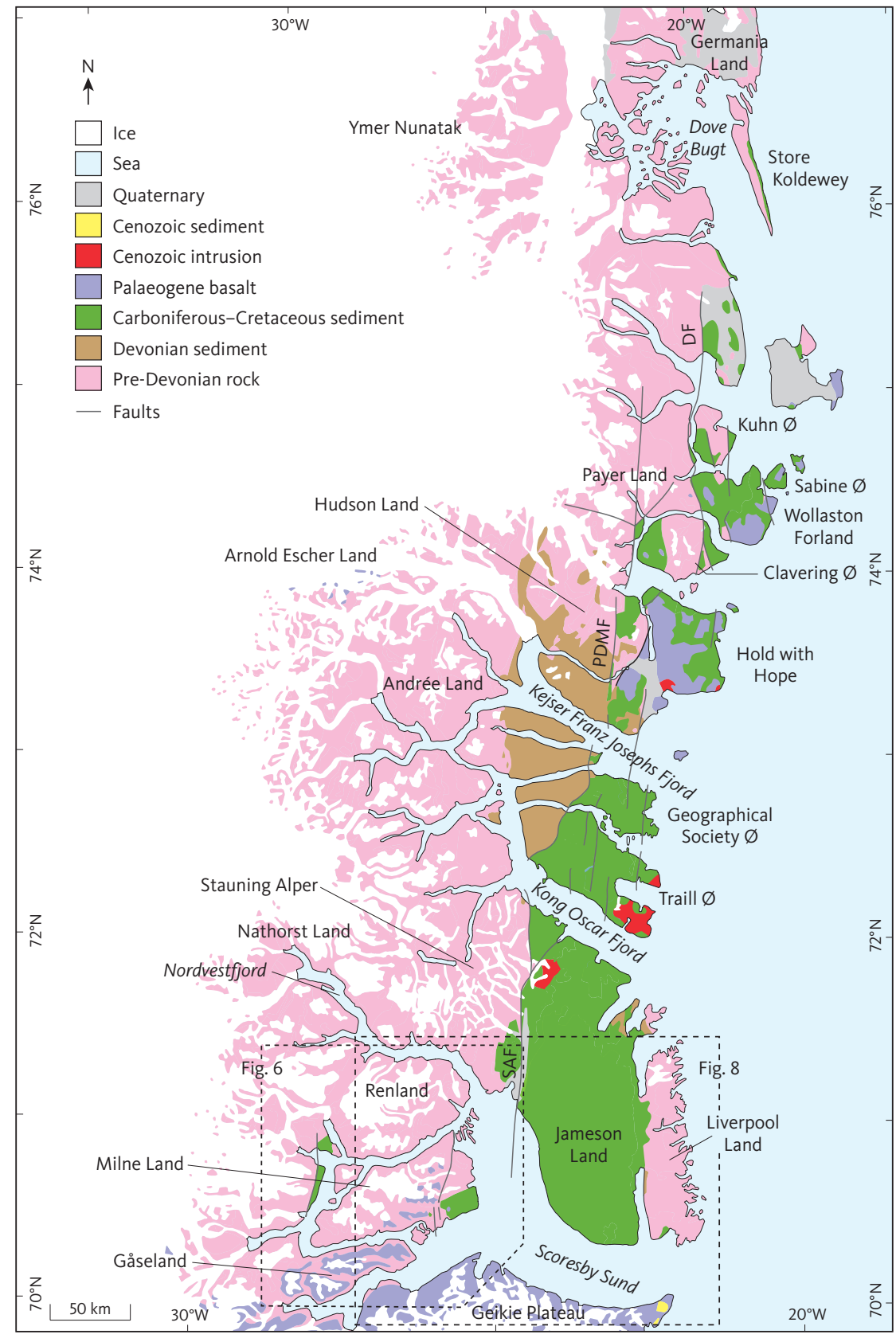

Fig. 4 Geology of the study area (70$78^{\circ} \mathrm{N}$; location in Fig. 1): DF: Dombjerg Fault. SAF: Stauning Alper Fault. PDMF: Post-Devonian Main Fault. We refer to the PDMF and the SAF as the Post-Devonian Main Fault system. Crystalline basement (Precambrian and Caledonian) and Devonian rocks dominate west of the PDMF with CarboniferousCretaceous rift basins to the east. Palaeogene flood basalts dominate much of the southern part of the study area, but patches of basalt occur as far north as $75^{\circ} \mathrm{N}$. Several Palaeogene intrusive centres occur along the coast. Black dashed lines: locations of Figs $6,8$. 
developed in East Greenland, forming N-S-trending, coast-parallel depocentres located to the east of the so-called post-Devonian Main Fault (Vischer 1943) - a north-north-east-trending fault, which appears as a marked scarp in the terrain, defining the present-day western boundary of the sedimentary basins north of Kong Oscar Fjord. South of the fjord, it is termed the Stauning Alper Fault. We will refer to these two faults as the post-Devonian Main Fault system. Important phases of rifting took place during the early and late Carboniferous, late Permian, late Jurassic and Cretaceous, prior to the opening of the North-East Atlantic at the Paleocene-Eocene transition (Surlyk 1990, 2003; Stemmerik et al. 1993; Stemmerik 2000; Surlyk \& Ineson 2003). Parsons et al. (2017) studied the geology of Traill $\varnothing$ and Geographical Society $\varnothing$ and identified three main rift phases during the Devonian-Triassic, Jurassic-Cretaceous and Palaeogene. The greatest amounts of faulting and block rotation occurred during Palaeogene rifting, which they related to the break-up at $56 \mathrm{Ma}$ and to the plate reorganisation at $36 \mathrm{Ma}$.

Break-up in the North-East Atlantic was accompanied by extrusion of voluminous flood basalts that dominate the region south of Scoresby Sund, along Blosseville Kyst and its hinterland $\left(68-70^{\circ} \mathrm{N}\right)$, where much of the lavas are referred to as the Main Basalts (Larsen et al. 1989; Brooks 2011). Palaeogene basalts are also present as far as $75^{\circ} \mathrm{N}$ (Larsen et al. 2014). The ages of the lava series near the coast in North-East Greenland range from 56 to $53 \mathrm{Ma}$, whereas the ages for lavas on inland nunataks in Arnold Escher Land range from 53 to $50 \mathrm{Ma}$ (Larsen et al. 2014). For comparison, the Main Basalts along Blosseville Kyst erupted during a time span of only one million years (56-55 Ma; Brooks 2011). The flood basalts along Blosseville Kyst attained a total vertical thickness of up to $5.5 \mathrm{~km}$, but subsidence kept pace with the thickness of extruded basalts. As such, individual lava flows can be traced over thousands of square kilometres, indicating a largely horizontal lava plain without significant relief (Larsen et al. 1989; Pedersen et al. 1997). Marine incursions onto the earliest and latest basalt flows along Blosseville Kyst show that the landscape was low-lying during the volcanic eruptions (Wager \& Deer 1939; Nielsen et al. 1981; Larsen et al. 1989, 2013; Pedersen et al. 1997; Larsen \& Tegner 2006; Brooks 2011). A phase of middle Miocene volcanism is documented by the presence of the lava flows of the Vindtop Formation (c. 14-13 Ma; Storey et al. 2004) that crop out on nunataks within a small area at 2.7-2.9 km a.s.I., just south of our study area (c. $\left.69^{\circ} \mathrm{N}\right)$. Pliocene-Pleistocene deposits within our study area are reported from Jameson Land, île de France (c. $78^{\circ} \mathrm{N}$ ) and Store Koldewey (Freyling-Hansen et al. 1983; Bennike et al. 2002, 2010).
Interpretation of seismic data off East Greenland has provided evidence for distinct tectonic activity along the margin during the late Eocene - early Oligocene and mid-late Miocene (Larsen et al. 1994a; Hamann et al. 2005; Døssing et al. 2016; Petersen 2019).

\subsection{Glacial history}

Stratigraphically extensive, ice-rafted debris, including macroscopic drop stones, occur in late Eocene to early Oligocene sediments from the Norwegian-Greenland Sea, indicating sediment rafting by continental ice and East Greenland as the likely source (Eldrett et al. 2007). Eldrett et al. (2009) presented climate estimates for the Eocene-Oligocene based on spore and pollen assemblages in marine sediments from the Norwegian-Greenland Sea. The climate estimates indicated cooling across the Eocene-Oligocene transition, but also provide evidence for relatively warm summer temperatures at that time, and thus that continental ice on East Greenland was probably restricted to alpine outlet glaciers.

A phase of exhumation in East Greenland starting near the Eocene-Oligocene transition was defined from thermochronology data and was argued to have been caused by glacial erosion (Bernard et al. 2016). However, the timing is consistent with the late Eocene phase of uplift and erosion defined by AFTA data in West, South-East and North-East Greenland Japsen et al. 2006, 2014, in press). This phase of exhumation in Greenland coincides with pronounced magmatic activity in East Greenland (Larsen et al. 2014), cessation of sea-floor spreading west of Greenland and with a major plate reorganisation in the North-East Atlantic (Gaina et al. 2009) and is thus likely to be of tectonic origin.

Studying ice-rafted debris from drill cores off SouthEast Greenland, Larsen et al. (1994a) concluded that full glacial conditions were established in South-East Greenland at $7 \mathrm{Ma}$. Similar evidence was identified in the borehole at Site 987 of the Ocean Drilling Program Leg 162 from the basin off Scoresby Sund. Here, upper Miocene - lower Pliocene sediments contain abundant ice-rafted debris and evidence for slumping and turbidity currents (Jansen et al. 1996; Channell et al. 1999).

Pérez et al. (2018) carried out seismo-stratigraphic analyses of Miocene to recent deposits on the continental shelf off Blosseville Kyst to Liverpool Land. Eight stratigraphic units were tied to the Ocean Drilling Program Site 987 . The formation of the oldest sedimentary unit (unit 8, between the early Miocene oceanic crust and a 7.3 Ma discontinuity) was controlled by major tectonic events along the margin, notably the late Miocene uplift episode at c. $10 \mathrm{Ma}$, as defined by AFTA data in rock samples from the Blosseville Kyst region (Japsen et al. 2014). Pérez et al. (2018) explained the 
high sediment input in this time interval by the presence of fluvial systems onshore. The subsequent, upper Miocene to lower Pliocene unit 7 (7.3-4.9 Ma) forms a widespread sedimentary body with isolated depocentres along the outer shelf, mostly off the major inland fjords. Pérez et al. (2018) inferred that cross-shelf glaciation began to influence the shelf during this interval at the time of the proposed onset of widespread glaciation in Greenland around $7 \mathrm{Ma}$, indicated by the occurrence of ice-rafted debris (Larsen et al. 1994a, 1994b; Jansen et al. 1996; Channell et al. 1999). Subsequently, two major phases of ice-sheet advance occurred across the shelf. First one was in the early Pliocene (unit 6), likely influenced by topographic forcing during early Pliocene uplift (Japsen et al. 2014). Second one was around the Pliocene-Pleistocene transition (unit 4). The deposits of the intervening phase (unit 5) reflect glacial retreat during the mid-Pliocene warm period (Raymo et al. 1996). Sedimentary successions from the Pleistocene to present (units 4-1) contain features that indicate that full-scale Greenland glaciation was established at 2.9 Ma (Sarnthein et al. 2009; Pérez et al. 2018).

Biomolecules from the silty section at the base of deep ice cores in central southern Greenland suggest that the region was forested sometime within the past million years (Willerslev et al. 2007). While measurements of cosmic-ray-produced isotopes in a bedrock core from central Greenland further indicate that Greenland was deglaciated for extended periods during the Pleistocene Epoch (2.6 Ma to 11.7 ka; Schaefer et al. 2016; see also Solgaard et al. 2013). The Greenland ice sheet that today has a thickness of up to $3 \mathrm{~km}$, thus, appears to have had a discontinuous history.

\subsection{Large-scale landscapes}

Here, we briefly review previous work on the large-scale landscapes in East Greenland. Altitudes in North-East Greenland vary significantly from a relatively low-lying terrain along the coast, across the Carboniferous-Palaeogene basins, to the elevated plains across crystalline basement, Devonian sediments and Palaeogene basalts further inland (Fig. 4). Elevation in the coastal zone rarely exceeds $1 \mathrm{~km}$ a.s.l.; however, the plateaus in the hinterland are typically around $2 \mathrm{~km}$ a.s.l., although Stauning Alper has peaks of up to $2.8 \mathrm{~km}$ a.s.l. (Figs 4, 5). The plateaus are often covered by thin ice, but north of $74^{\circ} \mathrm{N}$ the ice sheet almost reaches the coast. The elevation contrast between the exhumed basins along the coast and the interior basement terrains is pronounced along the post-Devonian Main Fault system.

A peneplain overlain by upper Permian, shallow marine sediments, has been identified both west and east of Jameson Land (Haller 1971; Larsen 1988; Surlyk 1990; Vigran et al. 1999; Stemmerik 2000). Surlyk (1990) concluded that the peneplain represents the latest Carboniferous to early Permian unconformity that marks the most profound change in tectonic style and overall depositional environment in the post-Caledonian development of East Greenland. This marks the transition from a long period of crustal extension to a period of subsidence governed mainly by thermal relaxation of the rifted crust.

A peneplain covered by Middle and Upper Jurassic sandstones of marine origin is exposed on Kuhn $\varnothing$ and Milne Land (Surlyk 2003; Surlyk \& Ineson 2003). Extensive denudation that started in the early Jurassic most likely led to the formation of this surface.

The landscape of the coastal areas of Jameson Land and Liverpool Land is the result of tertiary plateau uplift that resulted in partial denudation of the Mesozoic basins according to Peulvast $(1988,1991)$. Peulvast (1988) described a $10 \mathrm{~km}$-wide westward-sloping plateau on Liverpool Land that he regarded as a sub-Triassic planation surface. Mapping showed that it disappeared to the west below the sediments on Jameson Land, while the surface was obliterated near the most uplifted parts on Liverpool Land. He regarded the westerly tilted surface on Jameson Land as mainly structural, although he speculated that some near-horizontal, post-Mesozoic peneplains might be present on Liverpool Land at 800-900 m a.s.l.

The unconformity between Palaeogene basalts and basement rocks on Milne Land and Gåseland was mapped by Larsen et al. (1989). They concluded that the basement formed a high ridge with irregular topography and large relative relief at the time of basalt eruptions, and that the basement acted as a barrier, directing various basalts flows. The saprolites encountered at the basement-basalt contact are kaolinitic (Birkelund \& Perch-Nielsen 1976).

The fjord landscapes from Jameson Land to Hudson Land was studied by Swift et al. (2008) who defined the 'first-order topography' based on a map combining elevation and slope together with elevation profiles and geology. They identified three elevational areas reflecting the main aspects of the geology, separated by escarpments along major geological boundaries. These include:

\section{Areas composed of Mesozoic strata to the east of the} post-Devonian Main Fault system that are generally of low elevation with low to moderate relief and gently incised.

2. Areas west of the post-Devonian Main Fault where the landscape is more elevated and steeply incised by fjords.

3. Areas composed of Caledonian crystalline basement in the south and east that have the highest elevations and the deepest incision. 


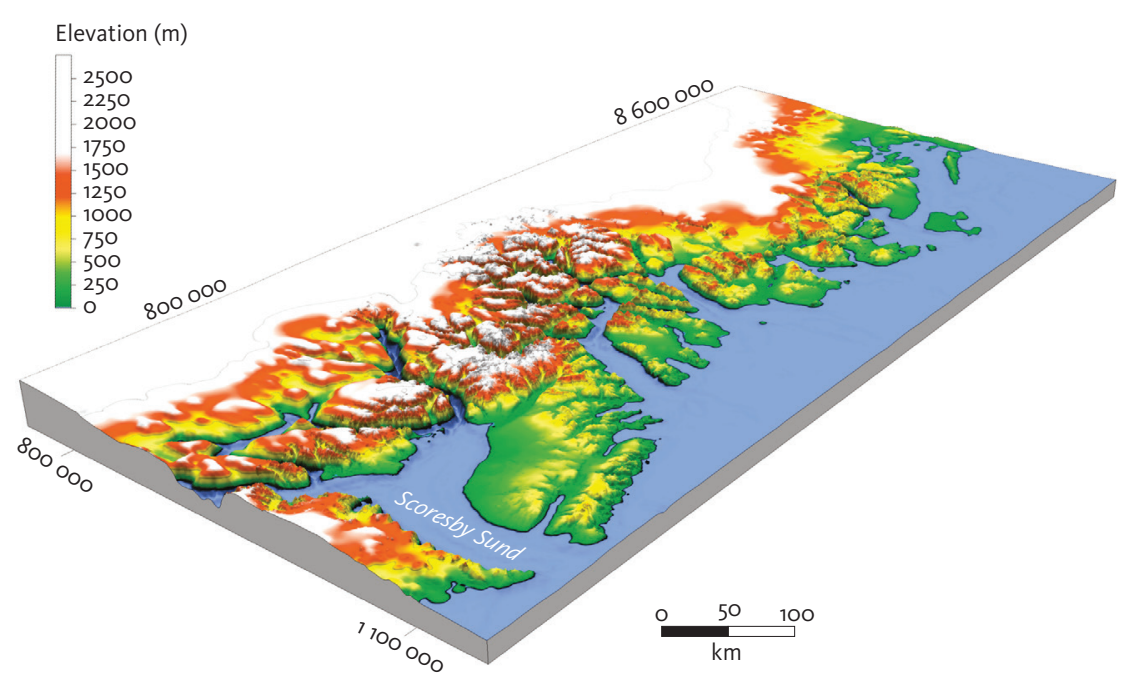

Fig. 5 Topography of the study area from Globe $1 \mathrm{~km}$ data (Globe Task team et al. 1999): The landscape at some distance from the coast is characterised by elevated plateaus dissected by deeply incised valleys. This configuration of landscape elements along a passive continental margin occurs on both glaciated and non-glaciated margins (e.g. Lidmar-Bergström et al. 2000; Green et al. 2013). Universal Transverse Mercator (UTM) coordinates (zone 27N) shown along the map frame.

A strong link between elevation and lithology was noted. In particular, the Caledonian basement was shown to have formed a consistent, high-elevation, low-relief landscape at c. $2000 \mathrm{~m}$ a.s.l., locally incised by the fjord system. The presence of Palaeogene sediments beneath Palaeogene basalts (Jolley \& Whitham 2004) indicated that the present-day first-order topography had existed prior to at least $55 \mathrm{Ma}$. The conclusions of Swift et al. (2008) were thus based on the configuration of the pre-basalt surface, and particularly on a contour map of that surface on Milne Land (Larsen et al. 1989), which they found to mirror the present topography. Finally, they found that glacial modification of the landscape is strongly influenced by first-order geology and hence lithological resistance to erosion.

The large-scale landscapes of North-East Greenland $\left(72-76^{\circ} \mathrm{N}\right)$ was studied by Ahlmann (1941) who demonstrated that topography could provide evidence of tectonic events in the past. His main conclusion is still important: '... the plateau and summit areas are the remains of what has once been a more or less uniform, high plateau rising towards the west'. He interpreted the elevated plateau there as the 'initial topography' from which the present relief had evolved by valley incision after uplift. AhImann argued that the landscape in North-East Greenland consisted of one plateau surface, dissected by valleys, and that the landscape was arched towards the present-day coastline. He observed that the plateau cuts across the basalt sequences and therefore concluded that it was an erosional surface that had formed after the extrusion of the volcanics. As the surface was incised by deep valleys, he deduced that the timing for the uplift to its present elevation was in the late Tertiary. Ahlmann's interpretation that the dominant topography is of post-basalt age is thus at odds with that of Swift et al. (2008), who considered it to be pre-basalt.

The regional post-basalt plateaus mapped by Ahlmann continue south of the study area, into the large-scale landscape between $68^{\circ} \mathrm{N}$ and $71^{\circ} \mathrm{N}$, studied by Bonow et al. (2014). This led to the identification of two elevated, post-basalt erosion surfaces of regional extent - the UPS and LPS. Bonow et al. (2014) concluded that these surfaces were the result of significant erosion, a conclusion that was in agreement with studies of the zonation of zeolite minerals in the Palaeogene basalts (Larsen et al. 1989; Neuhoff et al. 1997). Collectively, these studies showed that up to $1200 \mathrm{~m}$ of basalts (and possibly younger rocks) have been removed since the extrusion of the volcanics in South-East Greenland. For example, at least $400 \mathrm{~m}$ was estimated to have been removed on Milne Land.

\section{Methods}

Fieldwork was conducted in the study area during the summer of 2008 and 2010, using a helicopter for reconnaissance field support and as a platform for obtaining oblique photographs. We mapped planation surfaces map between $70^{\circ} \mathrm{N}$ and $78^{\circ} \mathrm{N}$, using the methods described by Bonow et al. (2014). We used the Global Land One-kilometre Base Elevation (GLOBE) digital elevation model for construction of a general 3D landscape model of the study area in East Greenland (Fig. 5) and we used the Advanced Spaceborne Thermal Emission and Reflection Radiometer (ASTER) Global Digital Elevation Model (GDEM; c. 30 m resolution) for

1. construction of a map with $100 \mathrm{~m}$ contours (Supplementary files S1, S2; Fig. 6)

2. construction of topographical profiles(Supplementary file S3; Fig. 6)

3. construction of swath profiles (Supplementary file S3; Fig. 6).

The elevation data contain some artefacts, for example, zero-value data occur in near-vertical mountainsides along fjords, resulting in data gaps in the model. There 
A B

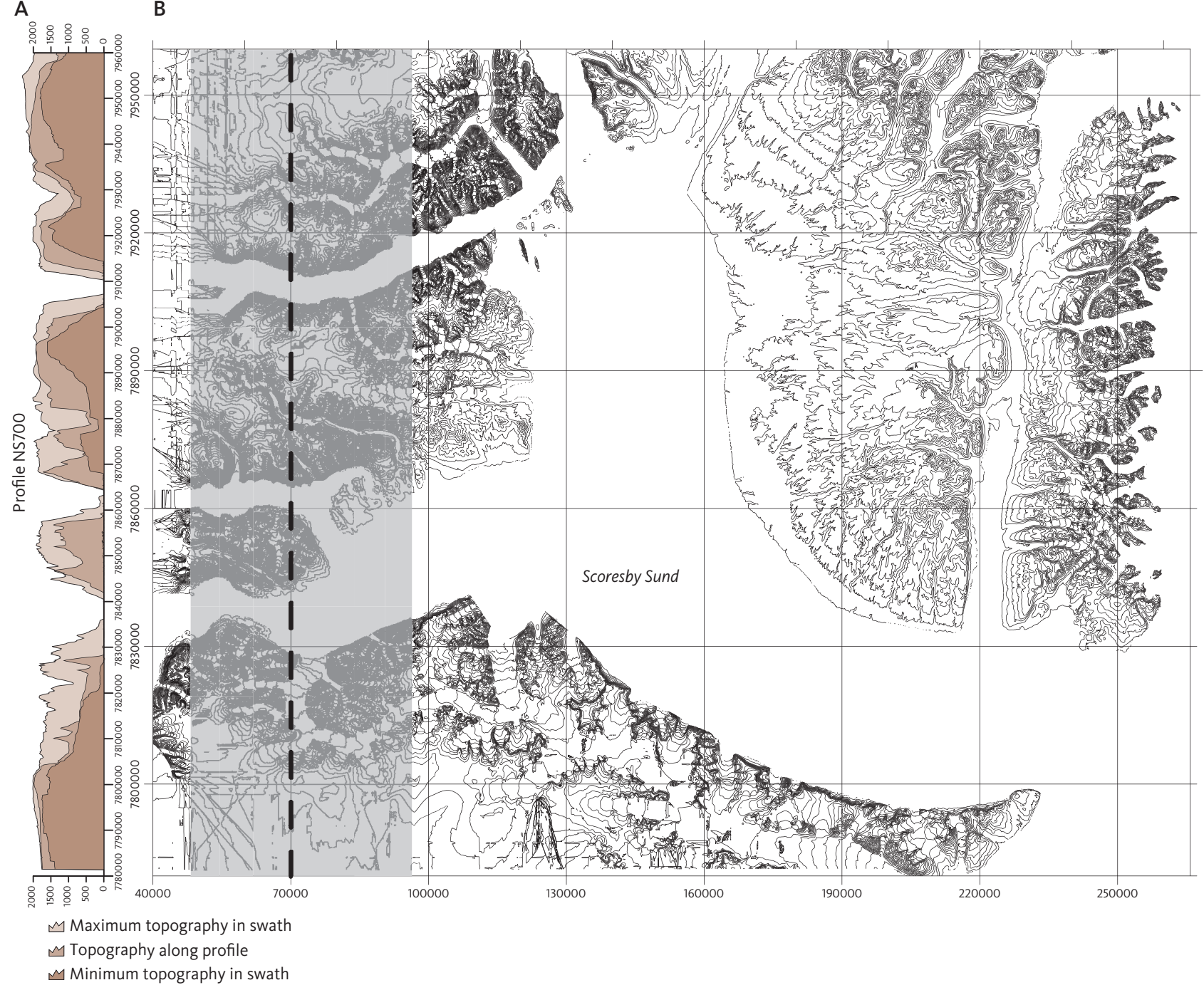

Fig. 6 Construction of topography profiles with minimum and maximum elevations within a swath: A: North-south profile with topography along the profile transect and with maximum and minimum elevations within the swath. X-axis: UTM northing (km). Y-axis: Elevation (km). Location in Fig. 4. B: The 100-m contour map constructed from ASTER data. These data are used in the surface mapping and to construct topography profiles. UTM coordinates indicated (km; UTM zone 27N). Grey area: 50-km wide swath used to calculate maximum and minimum elevation along the profile. Black dashed line: the actual topography along profile shown in panel A.

are also some extreme values that result in erroneous peaks in the model. Further, elevation data are rather poor in areas where small, melt-water lakes appear on the ice sheet surface.

Topographical profiles were extracted from the ASTER elevation data along a square grid, spaced $25 \mathrm{~km}$ apart. Maximum and minimum elevations along the topographical profiles were also extracted in a $50-\mathrm{km}$ wide swath. The profiles were printed on paper strips to the same scale as the contour map (1:500 000). The topographical profiles in combination with the swath profiles were used to support the mapping (Fig. 6). We cross-analysed 58 profiles with a cumulative length equal to $20000 \mathrm{~km}$.

The mapping of the surfaces started in areas of low relative relief with only minor fluvial incision. We determined the edge of a surface where there was a rapid change of inclination as seen from closely-spaced contours on the contour map. In the low-relief areas, maximum elevation along the swath coincides with the topographical profile, and thus provides a means of expanding the surface mapping into the dissected areas. This method of combining profiles and a contour map is useful for identifying offsets and tilting within a surface (see Lidmar-Bergström 1988; Bonow et al. 2006b, 2014).

We cross-checked the interpretation made on the contour map from profile to profile to ascertain that the interpretation was consistent. We also compared the mapped surfaces with the geological maps (Bengaard et al. 2007, topographical maps (GEUS 2007) and oblique photographs from the archives of the Geological Survey of Denmark and Greenland (GEUS). 


\section{Results}

This study overlaps with the mapping of Bonow et al. (2014) in the area between $70^{\circ} \mathrm{N}$ and $71^{\circ} \mathrm{N}$, where we identify the same elevated landscape features - the UPS and LPS (Figs 7, 8). We see that these features extend across Northeast Greenland between $70^{\circ} \mathrm{N}$ and $78^{\circ} \mathrm{N}$ (Figs 5, 9), and so they are the focus of the mapping and analysis in the current study. We also report the mapping of an exhumed etch surface (ES) formed by deep weathering (Supplementary files S1, S2). High-resolution contour maps for the northern and southern parts of the study area, overlain with the outline of the erosion surfaces, are provided as Supplementary files S1 and S2, respectively. Topographic profiles are also provided as a Supplementary file S3.

\subsection{Mapping of erosion surfaces \\ 5.1.1 The deeply weathered basement}

Around Milne Land and Gåseland, weathered basement rocks are exposed at their contact with both Palaeogene basalts (Fig. 10) and Jurassic sediments (Fig. 11). A detailed analysis of these sub-Palaeogene and subJurassic, weathered surfaces is beyond the scope of this paper. However, these surfaces are important as they provide snapshots of the erosional and depositional pre-basalt history of the margin. For example, the presence of weathered basement that crops out below marine Jurassic sediments shows that after the period of weathering and erosion of the land surface, prior to the Jurassic, the landscape was buried during subsidence, resulting in deposition of the marine sediments. A later

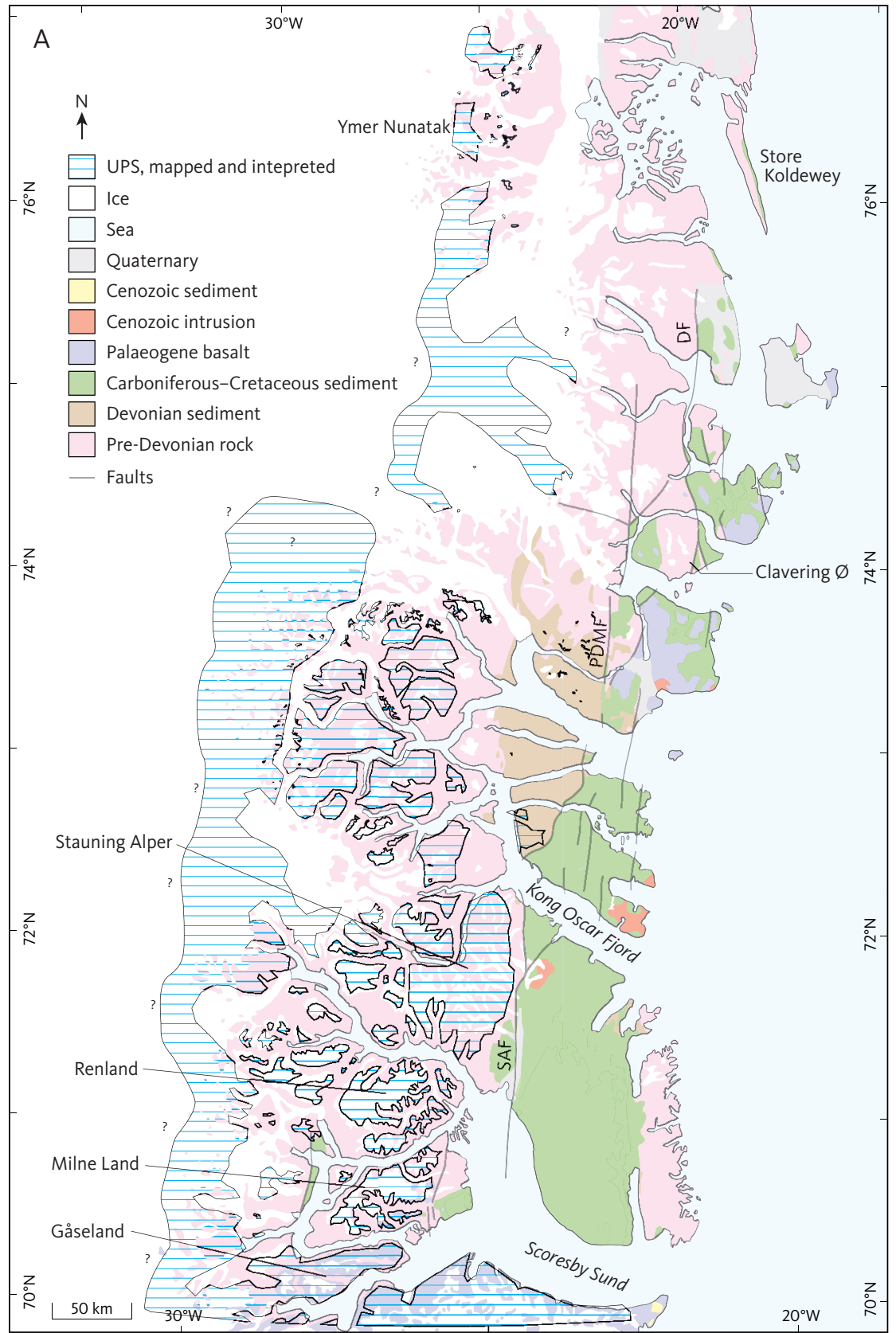

Fig. 7 Outlines of the Upper Planation Surface (UPS) and Lower Planation Surface (LPS) in North-East Greenland: A: UPS. B: LPS. See Fig. 4 for additional place names and supplementary files S1 and S2 for maps of these surfaces at 1:500 000 scale. 
phase of uplift that must have occurred after the Jurassic raised the marine sediments to their present position in the landscape, which are now visible overlying the weathered basement. This is geological evidence of an episodic development of the landscape, in contrast to the frequent assumption of a progressive emergence of the bedrock (e.g. Pedersen et al. 2012).

The outline of the weathered basement is shown in Supplementary file S1, and some of the details of the weathered basement are discussed by Larsen et al. (1989). Where a bedrock surface is formed by deep weathering, its character does not depend on the age of the cover rocks, for example, Jurassic sediments or Paleocene basalts. For the purpose of this paper, which is to distinguish between the pre-basalt and the post-basalt landscape development, we chose to refer to these different pre-basalt surfaces as a single ES, as this term describes the formation process, the characteristics of saprolites and the general hilly relief shape of the basement (e.g. Bonow 2005).

The ES can be mapped with high confidence close to cover rocks, but it is more difficult to identify in areas with no cover and further away from cover rocks. It is especially difficult to identify deeply weathered surfaces in formerly glaciated areas because classical roche moutonnée landscapes (e.g. Sugden 1974; Glasser \& Warren 1990; Freire et al. 2015) are highly similar in shape to bedrock forms shaped by weathering (Lindström 1988; Sugden et al. 1992; André 2001, 2002; Migoń \& Lidmar-Bergström 2001; Bonow 2005; Krabbendam \&

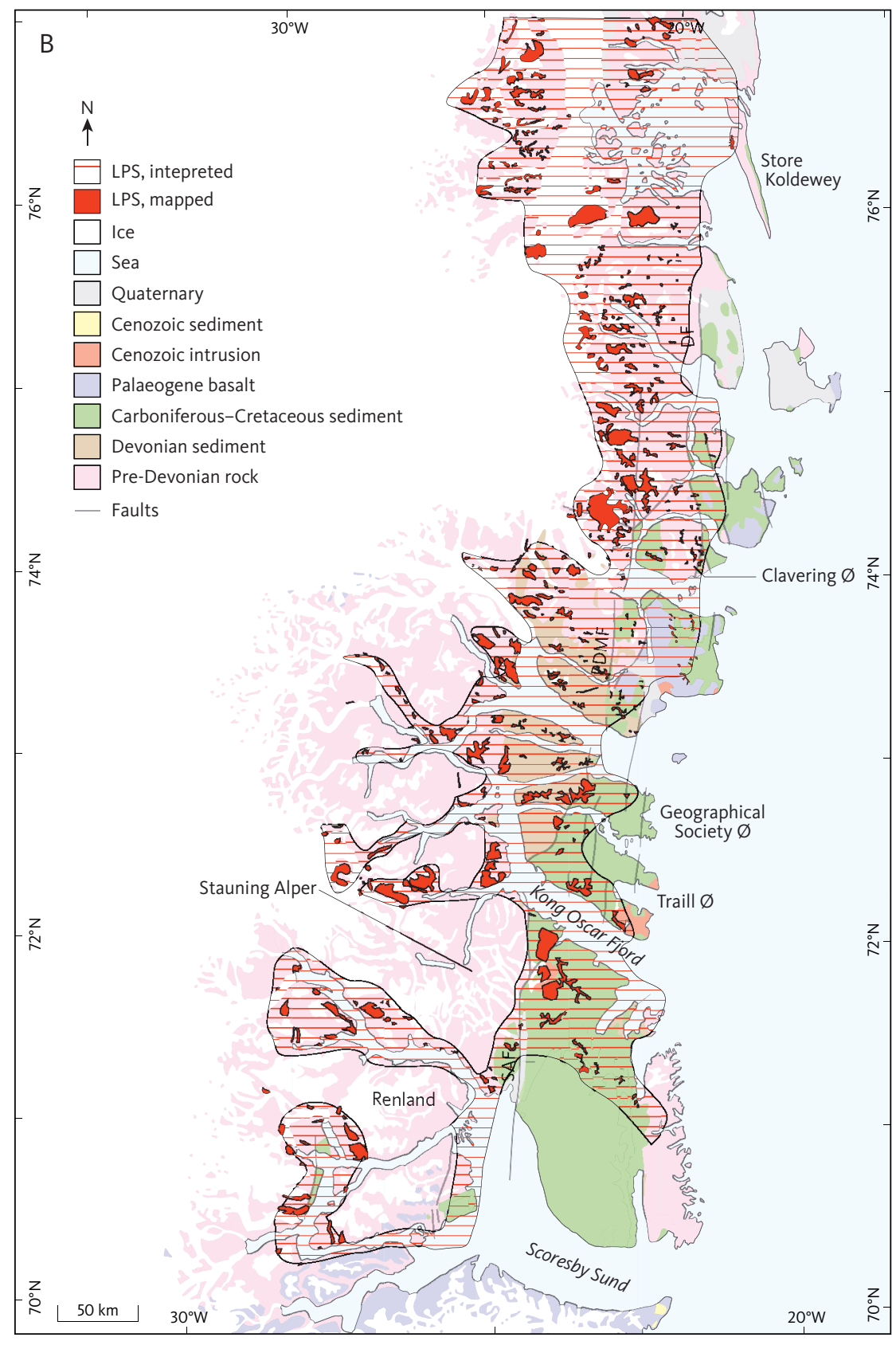

Fig. 7 (Continues) Outlines of the Upper Planation Surface (UPS) and Lower Planation Surface (LPS) in North-East Greenland: A: UPS . B: LPS. See Fig. 4 for additional place names and supplementary files $\mathrm{S} 1$ and $\mathrm{S} 2$ for maps of these surfaces at 1:500 000 scale. 


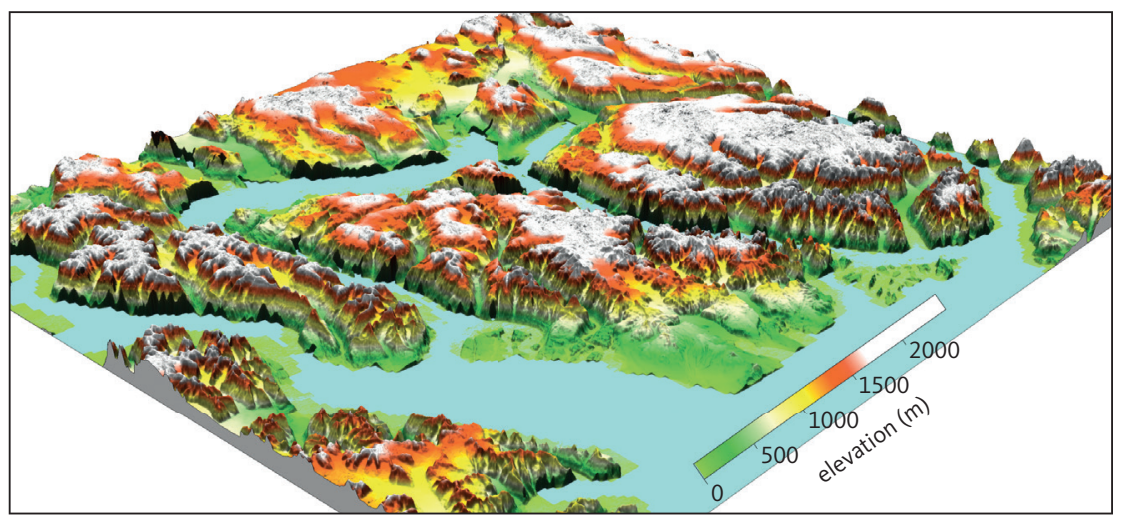

Fig. 8 3D model from ASTER data showing the characteristic landforms in the region around Gåseland, Milne Land and Renland: A: 3D model with no labels. B: The same 3D model with labels. The Upper Planation Surface (UPS) is well preserved, while the Lower Planation Surface (LPS) is mainly identified along the main valleys. The inclined Jurassic etch surface (ES) is identified in eastern Milne Land where it is cut off by the UPS. Location in Fig. 4.

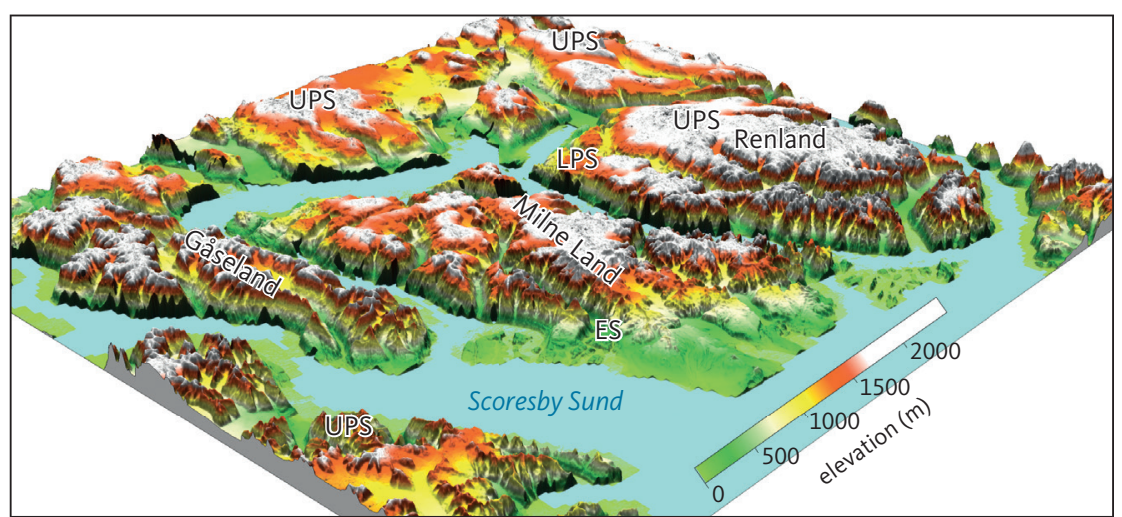

Bradwell 2014; Lidmar-Bergström et al. 2017; Hall et al. 2020). All parts of the identified ES in the study area are close to cover rocks and thus, we have high confidence in our mapping of its extent. On Milne Land, the tilted ES is cut off by the near-horizontal UPS that formed across both basement and basalts, which shows that the UPS formed after the ES (Figs 11, 12).

\subsubsection{The Upper Planation Surface}

The UPS dominates the landscape away from the coast, especially south of $74^{\circ} \mathrm{N}$. The UPS is up to 200 $\mathrm{km}$ wide and extends across the study area for more than $900 \mathrm{~km}$ in north-south direction. Photographs provide further visual evidence of the continuity of the UPS across wide areas (Figs 11-14). North of $74^{\circ} \mathrm{N}$, the UPS disappears below the Greenland ice sheet. The UPS is to a large extent covered by ice due to its high elevation at around $2 \mathrm{~km}$ a.s.l. The ice increases in thickness towards the west. In the northernmost part of the study area, the UPS occurs at slightly lower elevation, c. 1.5 $\mathrm{km}$. South of Scoresby Sund the UPS becomes more elevated (above $3 \mathrm{~km}$ ) in the Kangerlussuaq area (c. $400 \mathrm{~km}$ south of the study area; Bonow et al. 2014). In the south, a flat bedrock surface was observed in section and photographed along the rim of incised valleys, emerging from beneath the thin ice caps. These plateau rims are typically too small to be represented on the maps, but these observations support the mapping and allowed us to interpret the bedrock surface as part of the UPS.

North of $74^{\circ} \mathrm{N}$, the UPS is represented by minor, flattish remnants located where the Greenland ice sheet becomes coherent (Fig. 7A); for example, Ymer Nunatak in the northernmost part of the study area (Fig. 4). It is not possible to assess the relief of these surfaces as only the rim is exposed from below the ice cover, but the rims appear to be flat. The correlation between the well-developed UPS in the south and the remnants in the north is less well constrained because of the ice cover and the long distance between them. Thus, in this part of the study area, it is not always clear how to correlate the surface on the topographical profiles.

In the south, especially on Milne Land and Gåseland, the UPS is developed across rocks of different age and of different resistance (Fig. 7A). For example, on Milne Land the UPS developed across Palaeogene basalt (Fig. 15A) and crystalline basement rocks (Fig. 15B) just a few kilometres apart and at about the same elevation. On Gåseland, the UPS is about $700 \mathrm{~m}$ below the original top of the volcanic pile as estimated from zeolite stratigraphy (Larsen et al. 1989; Fig. 12), offering further evidence that the position of the UPS is not defined by structural control on a regional scale from flat-lying lava flows.

The UPS cuts across the Palaeogene basalts at about $2.2 \mathrm{~km}$ a.s.l. in Arnold Escher Land, located about $200 \mathrm{~km}$ from the coast and close to the ice sheet $\left(74^{\circ} \mathrm{N}, 28^{\circ} \mathrm{W}\right.$; 
Fig. 4). The UPS is thus mainly preserved in basalts and basement rocks in the southern part of the study area. However, the landscapes across the sedimentary basins near the coast are characterised by many ridges and minor flattish summits that reach the projected level for the UPS, even in areas such as Traill $\varnothing$ with sedimentary rocks at $1800 \mathrm{~m}$ a.s.l.

Offsets of the UPS along the topographical profiles would indicate tectonic movements after the formation of the UPS. We could not identify any, but some movements cannot be ruled out as the ice covering the UPS obscures its precise identification in many places, and correlating the UPS across a fjord or a valley is occasionally problematic. Where there are offsets, however, they are only minor, indicating that the entire region where the UPS is preserved has been uplifted and appears to have acted as a single tectonic unit. A deviation from this pattern occurs in Stauning Alper where the summits reach an elevation of $2.8 \mathrm{~km}$ a.s.I. - the highest elevation within the study area. Even though no remnants of the UPS were identified in this area, it was possible to use the swath profiles to reconstruct the elevation of the UPS fairly well (Fig. 16). The contours of the UPS define a dome around Stauning Alper, whose highest area is above c. $2.3 \mathrm{~km}$ a.s.l. (Fig. 9A). The domal pattern of the UPS in this region indicates that a fairly localised, tectonic movement occurred after the formation of the UPS. South of the study area, in the Blosseville Kyst region, the elevation of the UPS increases and approaches 3.5 km a.s.l. near Gunnbjørn Fjeld, which at 3.7 km a.s.l. is the highest mountain in Greenland (Bonow et al. 2014).

The UPS is well defined across large areas, but less so where only a limited part of the UPS is preserved, including coastal areas with only a narrow ice-free landmass. Here, the precise extent and the correlation of the surface between profiles (especially in north-south direction) are uncertain. This is the case for the UPS across most of the sedimentary areas in the east and in the region north of $74^{\circ} \mathrm{N}$. Another source of uncertainty is the presence of extensive ice caps that cover much of the surface. This problem cannot be solved completely, but the presence of minor remnants of flat surfaces or nunataks, supports the interpretation that the UPS is present below the ice. This is further supported by the occurrence of outliers of Palaeogene basalts on the inland nunataks in Arnold Escher Land that are equivalent to, but slightly younger than, the basalts on Milne Land (Fig. 4; Larsen et al. 2014).

In summary, the formation of the UPS must have been governed by the general base level at the time of formation, as the surface cuts across rocks of different age and resistance (Figs 11-13, 15). Therefore, the UPS is not a structural surface, such as the top of the last basalt flow, which an investigation of a minor area might suggest. Since the UPS developed after the extrusions of the Palaeogene basalts and the onset of sea-floor spreading in the North-East Atlantic, the general base level must have been the Atlantic Ocean. Hence, we can consider the UPS as a peneplain.

\subsubsection{The Lower Planation Surface}

The LPS typically occurs at c. $1 \mathrm{~km}$ a.s.l. and it extends across a 50 to $75 \mathrm{~km}$ wide zone (up to $100 \mathrm{~km}$ ) inland from the coast (Fig. 7B). It also exists as wide-valley benches along some of the major fjords further inland (Figs 17, 18). In the areas where sedimentary rocks crop out, the LPS is defined by flat-topped summits that make up a coherent surface, while in areas with basement rocks, the LPS is more extensive and less dissected (Fig. 18). North of $74^{\circ} \mathrm{N}$, the LPS dominates the ice-free areas of the upper-plateau landscape in near-coastal areas (Fig. 7B). However, south of $74^{\circ} \mathrm{N}$, the LPS and the UPS co-exist, and the LPS can occasionally be followed as a wide-valley bench along some of the major valleys (Figs 9, 17). The LPS reaches an elevation of $2 \mathrm{~km}$ a.s.l. in the southern part of the Blosseville Kyst area (c. $68^{\circ} \mathrm{N}$; Bonow et al. 2014), where it is continuous across different rock types with significantly different resistance to erosion. The difference in geology defines how developed the LPS is; that is, less developed in resistant rock and vice versa. The LPS is incised below the UPS, and therefore younger.

The LPS thus extends from valley benches in basement rocks in the interior to plateau remnants in sedimentary rock at the same elevation closer to the coast. This supports the finding that the formation of the LPS was controlled by the fluvial system and thus graded towards the new base level, which again must have been the Atlantic Ocean, and hence we can also consider the LPS to be a peneplain.

\subsubsection{Escarpments and faults}

The post-Devonian Main Fault system is a prominent feature that runs north-south through the study area (Fig. 4). East of the fault, where sediments are exposed, the UPS is not present, possibly because it has been destroyed. The LPS, however, is defined on both sides of the post-Devonian Main Fault at about the same elevation (Fig. 7B). West of the fault, the LPS is defined by wide-valley benches, and the surface continues at the same elevation east of the fault, where it is defined by flat-topped summits. The escarpment between the UPS and the LPS follows along the major valleys.

\subsection{Relative denudation chronology and magnitude of uplift}

\subsubsection{Constraints on the timing for the formation of the UPS and LPS}

The UPS post-dates the extrusion of the basalts in the Paleocene-Eocene transition (c. $56 \mathrm{Ma}$ ) as the surface truncates both the Palaeogene basalts and older 


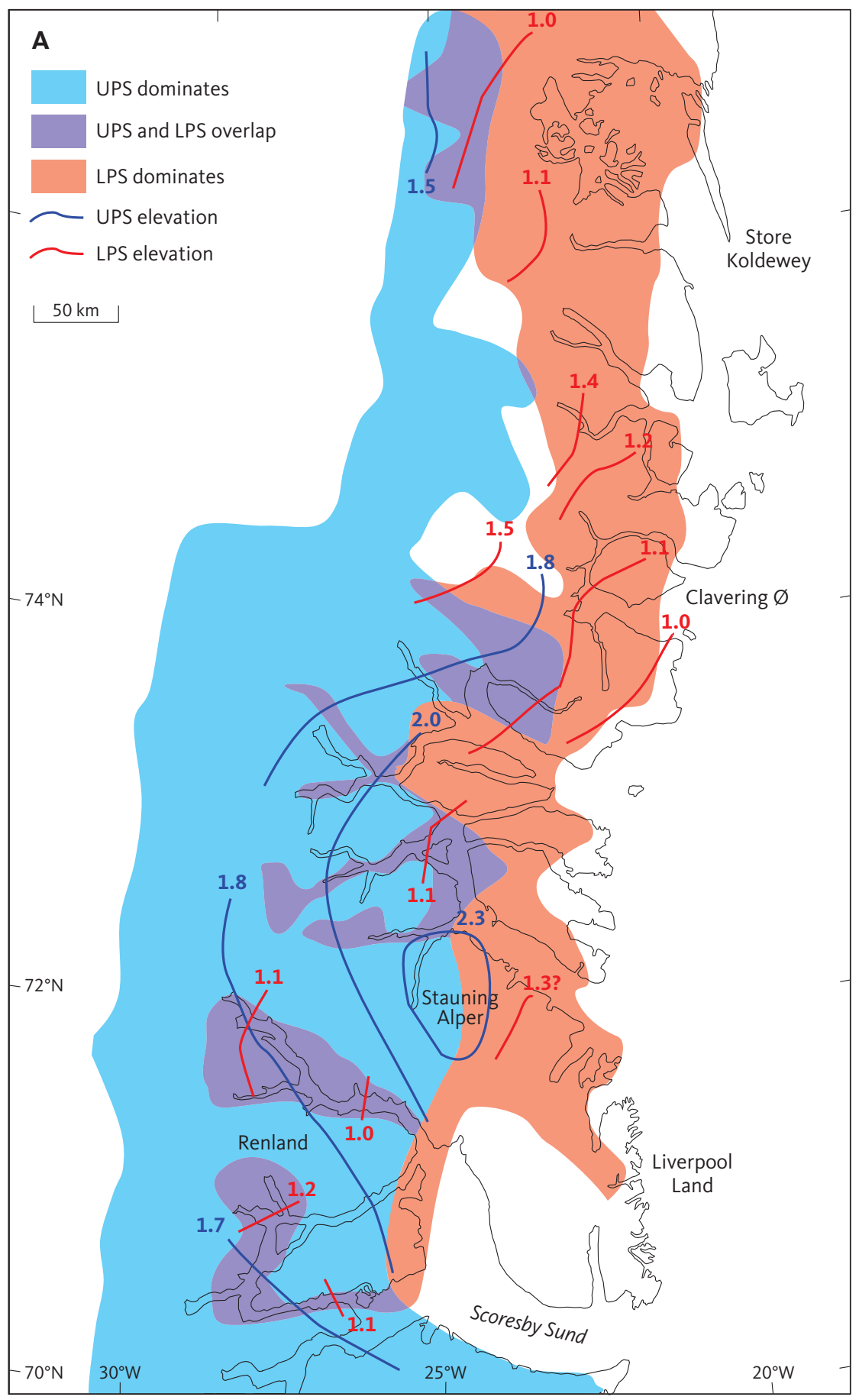

Fig. 9 Extent and elevation of the Upper and Lower Planation Surface (UPS and LPS): A: UPS and LPS shown with elevation contours. B: UPS and LPS annotated with the location and orientation of Figs 10-20. The UPS is typically $2 \mathrm{~km}$ a.s.l., identified mainly south of $74^{\circ} \mathrm{N}$ at some distance from the coast. North of $74^{\circ} \mathrm{N}$, the UPS is identified only as small remnants close to the Greenland ice sheet. The LPS is typically $1 \mathrm{~km}$ a.s.l. and coalesces to form a coherent surface towards the coast. Note the dome structure of the UPS centred on Stauning Alper, which suggests tectonic doming after formation of the UPS.

rocks. The wide areal extent and low relative relief of the surface indicate long-term, tectonically stable conditions during its formation as, given enough time, resistant rocks will be denuded until all significant topographical expression has been removed (Fig. 2). This could take several million years, as was suggested for West Greenland (Bonow et al. 2006b, 2007a, 2007b; Japsen et al. 2009). We therefore find that the UPS represents a single erosional phase that affected East Greenland, at least between $68^{\circ} \mathrm{N}$ and $78^{\circ} \mathrm{N}$ as documented in this paper and by Bonow et al. (2014).
The presence of the mid-Miocene lava flows of the Vindtop Formation (14-13 Ma; Storey et al. 2004), south of our study area $\left(69.18^{\circ} \mathrm{N}\right)$, provide further constraints on the timing of the formation of the UPS. The Vindtop Formation rests on the Palaeogene basalts in a small area between 2.7 and $2.9 \mathrm{~km}$ a.s.l. According to the mapping of Bonow et al. (2014), this unconformity corresponds to the UPS and this implies that the UPS had formed prior to the eruption of the mid-Miocene volcanics, well before the onset of the Plio-Pleistocene glaciations (c. $2.7 \mathrm{Ma}$; Shackleton et al. 1988). As the valley benches associated with the 


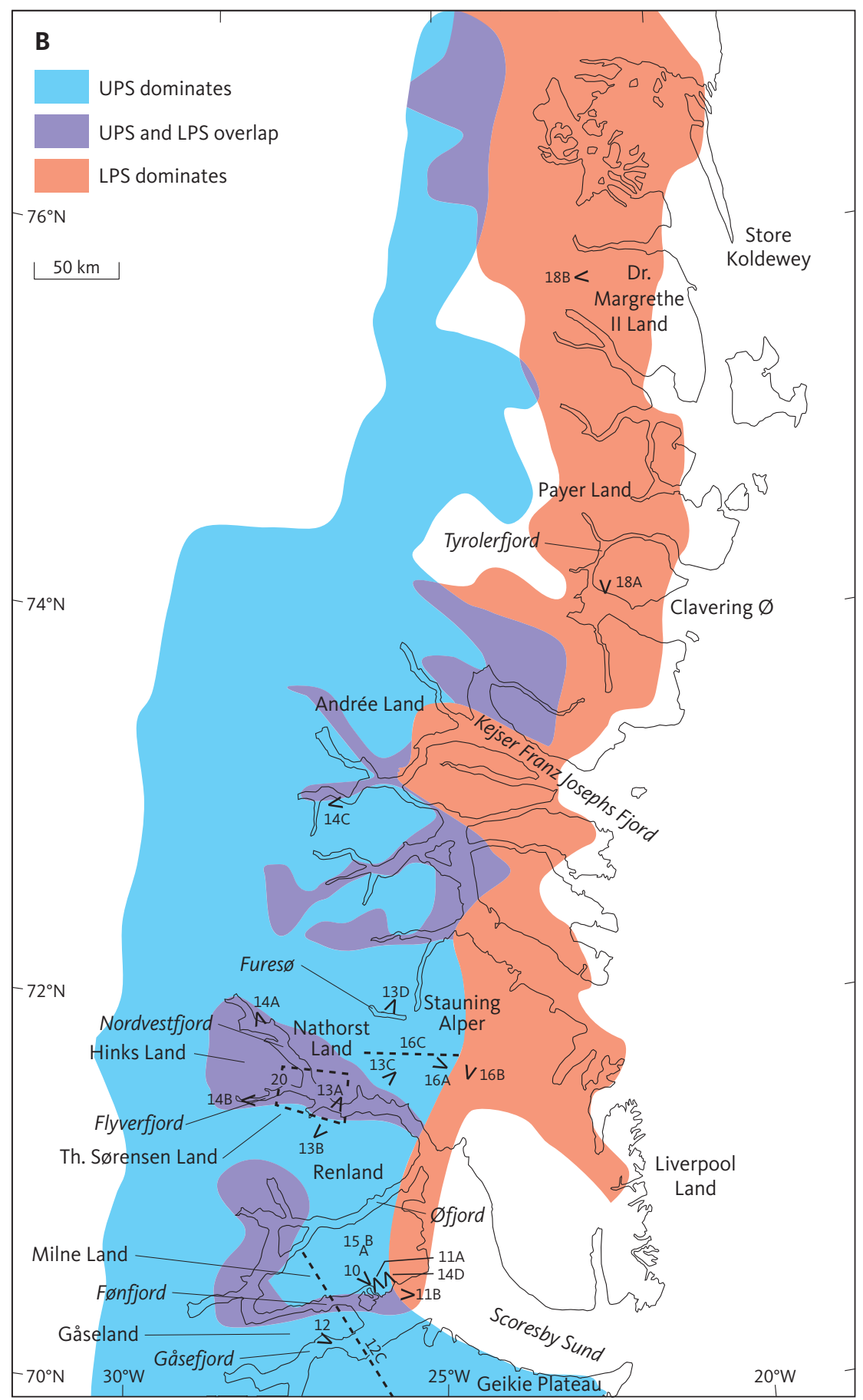

Fig. 9 (Continues) Extent and elevation of the Upper and Lower Planation Surface (UPS and LPS): A: UPS and LPS shown with elevation contours. B: UPS and LPS annotated with the location and orientation of Figs $10-20$. The UPS is typically 2 $\mathrm{km}$ a.s.l., identified mainly south of $74^{\circ} \mathrm{N}$ at some distance from the coast. North of $74^{\circ} \mathrm{N}$, the UPS is identified only as small remnants close to the Greenland ice sheet. The LPS is typically $1 \mathrm{~km}$ a.s.l. and coalesces to form a coherent surface towards the coast. Note the dome structure of the UPS centred on Stauning Alper, which suggests tectonic doming after formation of the UPS.

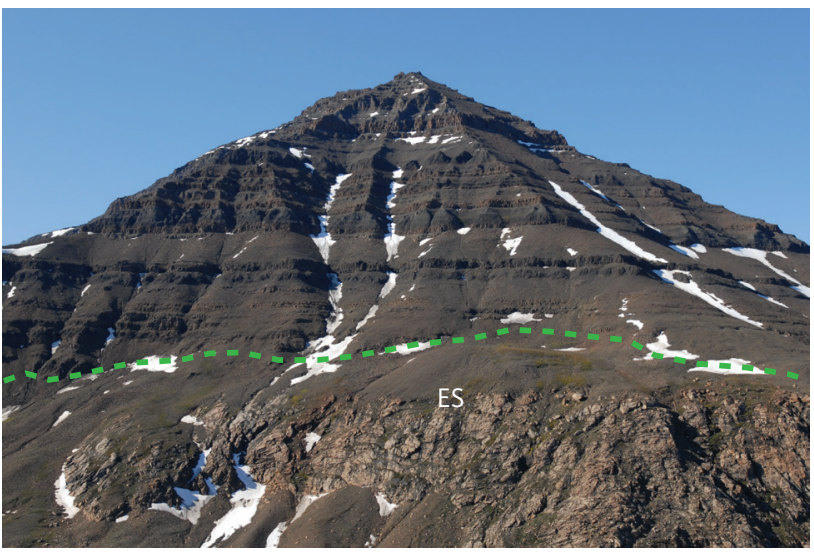

Fig. 10 The contact between Palaeogene basalt and crystalline basement is the re-exposed etch surface (ES), Milne Land: The basement is weathered and kaolinitic saprolites are found at the contact (e.g. Larsen et al. 1989). Photo location in Fig. 9. 

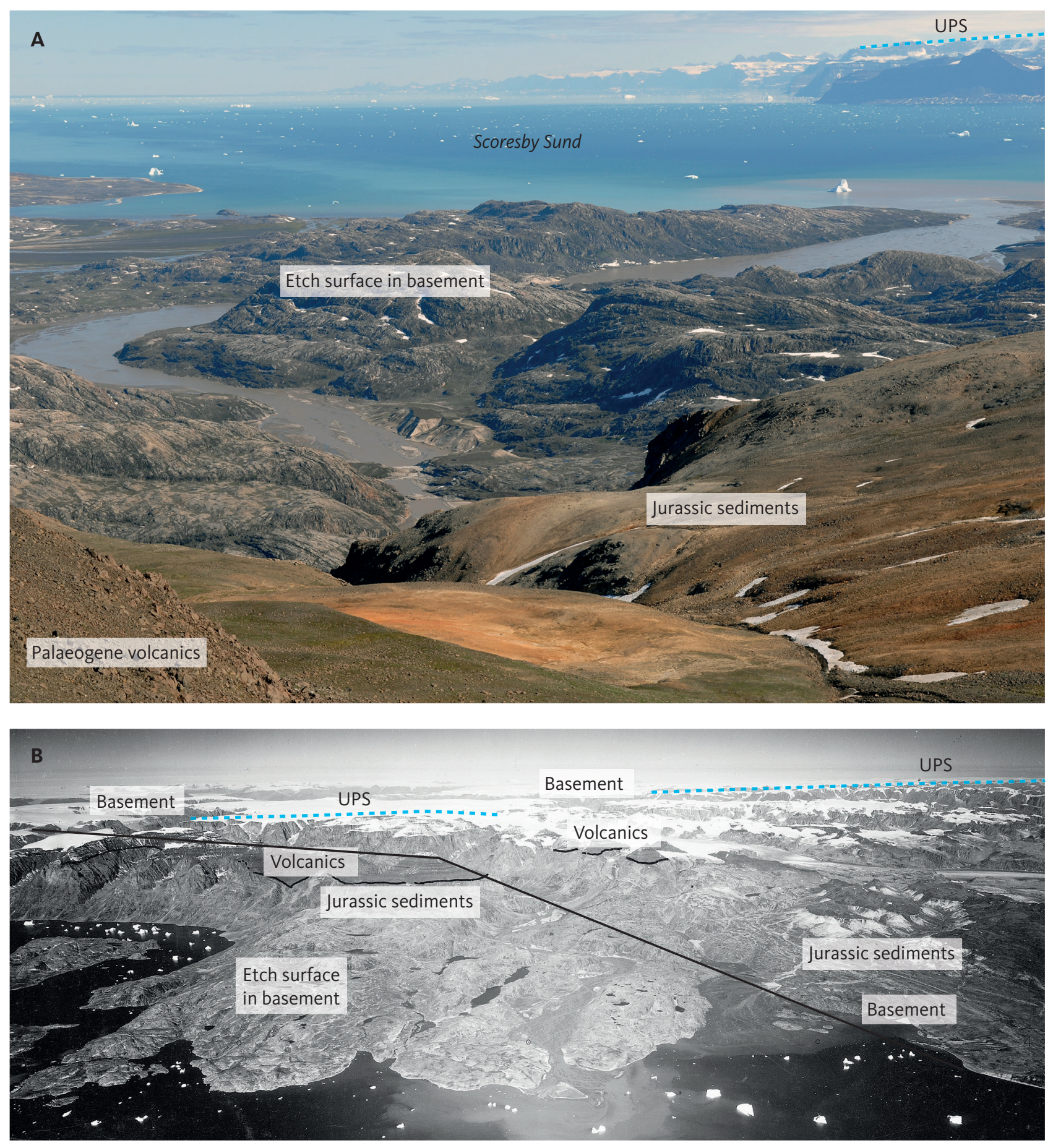

C

Elevation $(\mathrm{km})$

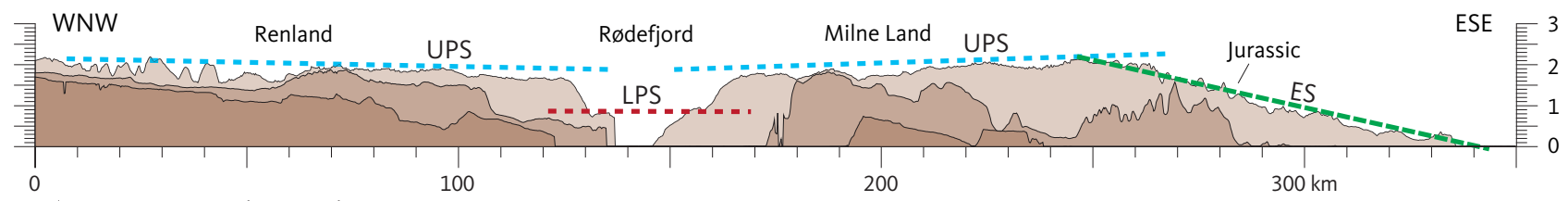

$M$ Maximum topography in swath

$M$ Topography along profile

$M$ Minimum topography in swath

Fig. 11 The relationship between the deeply weathered basement (etch surface, ES) overlain by the Middle Jurassic Charcot Bugt Formation and Palaeogene basalts on southern Milne Land. The Upper Planation Surface (UPS) truncates the sub-Jurassic ES and the basalts. Location of photographs and profile are shown in Fig. 9. A: View from southern Milne Land across Scoresby Sund towards the Geikie Plateau where the UPS cuts across the basalts. The tilted ES of sub-Jurassic age is characterised by distinct hills defined by intensively weathered fracture systems prior to the deposition of the cover rocks. Jurassic sediments rest on the ES, which therefore constrains the final formation age of this surface. B: View of a tilted ES on southern Milne Land looking northwest. The extensive UPS is developed across Renland and beyond. The UPS truncates both the basement and the volcanics, which constrains the UPS as younger than the Palaeogene basalts (see also Fig. 15). Note that Jurassic sediments cover the ES, but also that valleys within the ES have been filled by basalt flows. This means that the Jurassic ES surface had been re-exposed prior to eruption of the Palaeogene basalts. Black line: Approximate location between the 210 and 340 km marks of the profile in C. Photo: Kort \& Matrikelstyrelsen, Denmark. C: Swath profile illustrates the relationship between three surfaces: ES, UPS and the Lower Planation Surface (LPS). 

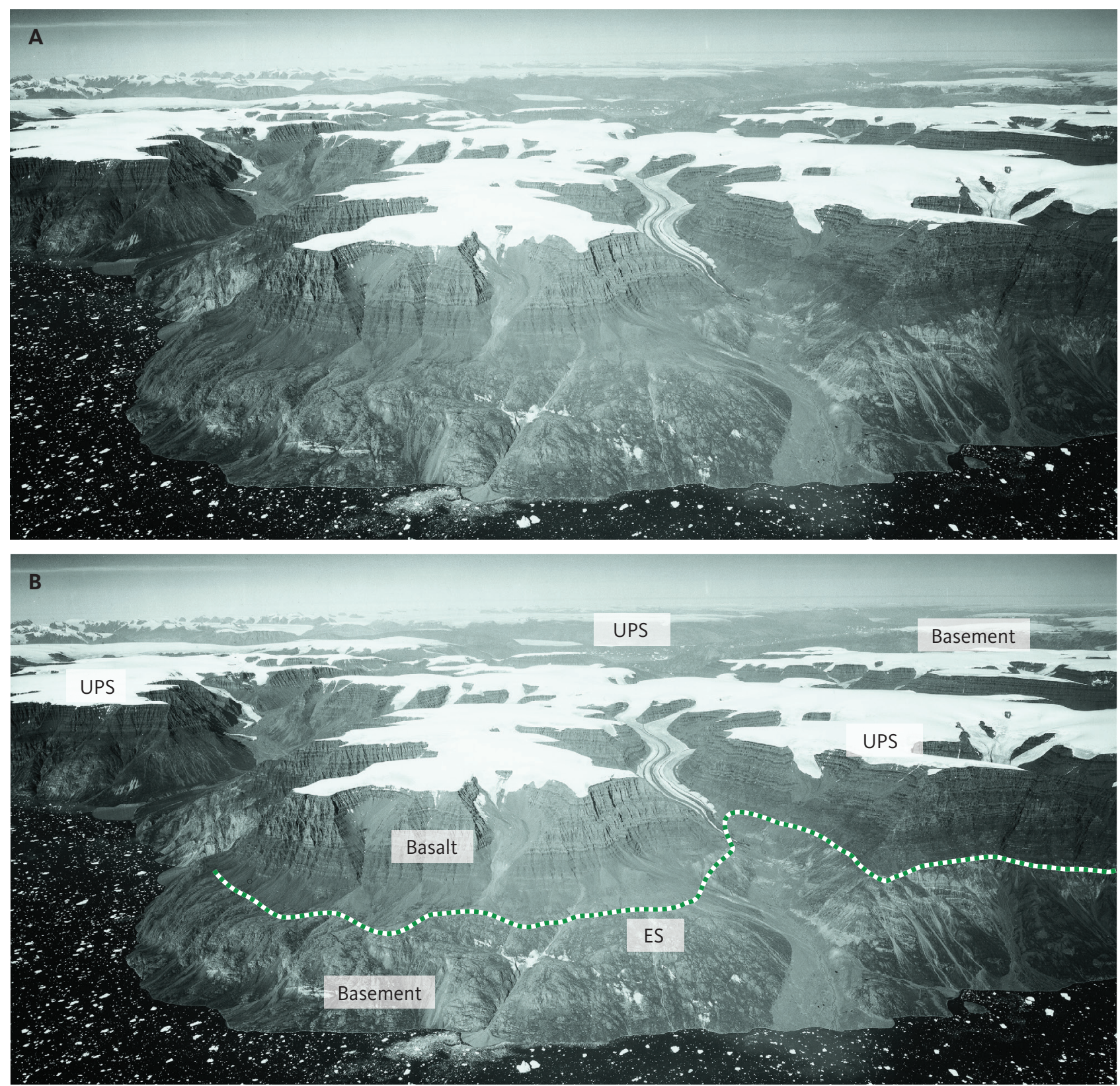

SE

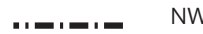

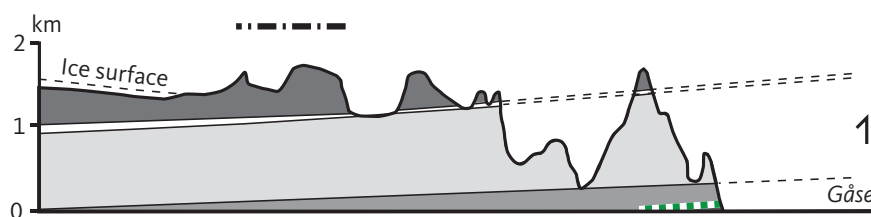

Geikie Plateau asefjord

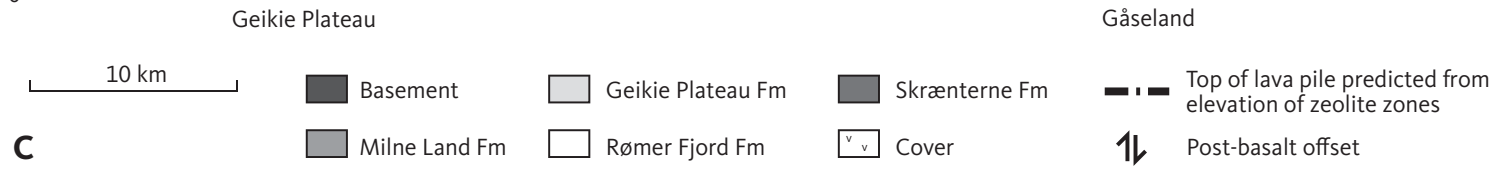

Fig. 12 The Upper Planation Surface (UPS) at an elevation of about $1800 \mathrm{~m}$ a.sl. developed across Palaeogene basalts on Gåseland. The UPS was likely formed by erosion after the extrusion of the volcanics. Locations shown in Fig. 9. A: View to the north-west across the inner part of Gåsefjord B: The volcanic strata are tilted south-east and about $700 \mathrm{~m}$ of basalt have been removed from above Gåseland (Larsen et al. 1989). The etch surface (ES) defines the base of the basalts. Photo: Kort \& Matrikelstyrelsen, Denmark. C: Topography profile showing the inclined and truncated strata of the Main Basalts and the original top of the lava pile estimated from the elevation of zeolite zones across Milne Land, Gåseland and Geikie Plateau. The present-day lava surface is consequently an erosional feature and the tilt and offset of the basalt formations are post-basalt features. The UPS on Gåseland shown in panel $\mathrm{B}$ is thus about $700 \mathrm{~m}$ below the original top of the volcanic pile. Note the tilt of four formations of the Main Basalts, Geikie Plateau Fm, Skrænterne Fm, Milne Land Fm and Rømer Fjord Fm. Based on Larsen et al. (1989) and Bonow et al. (2014). 

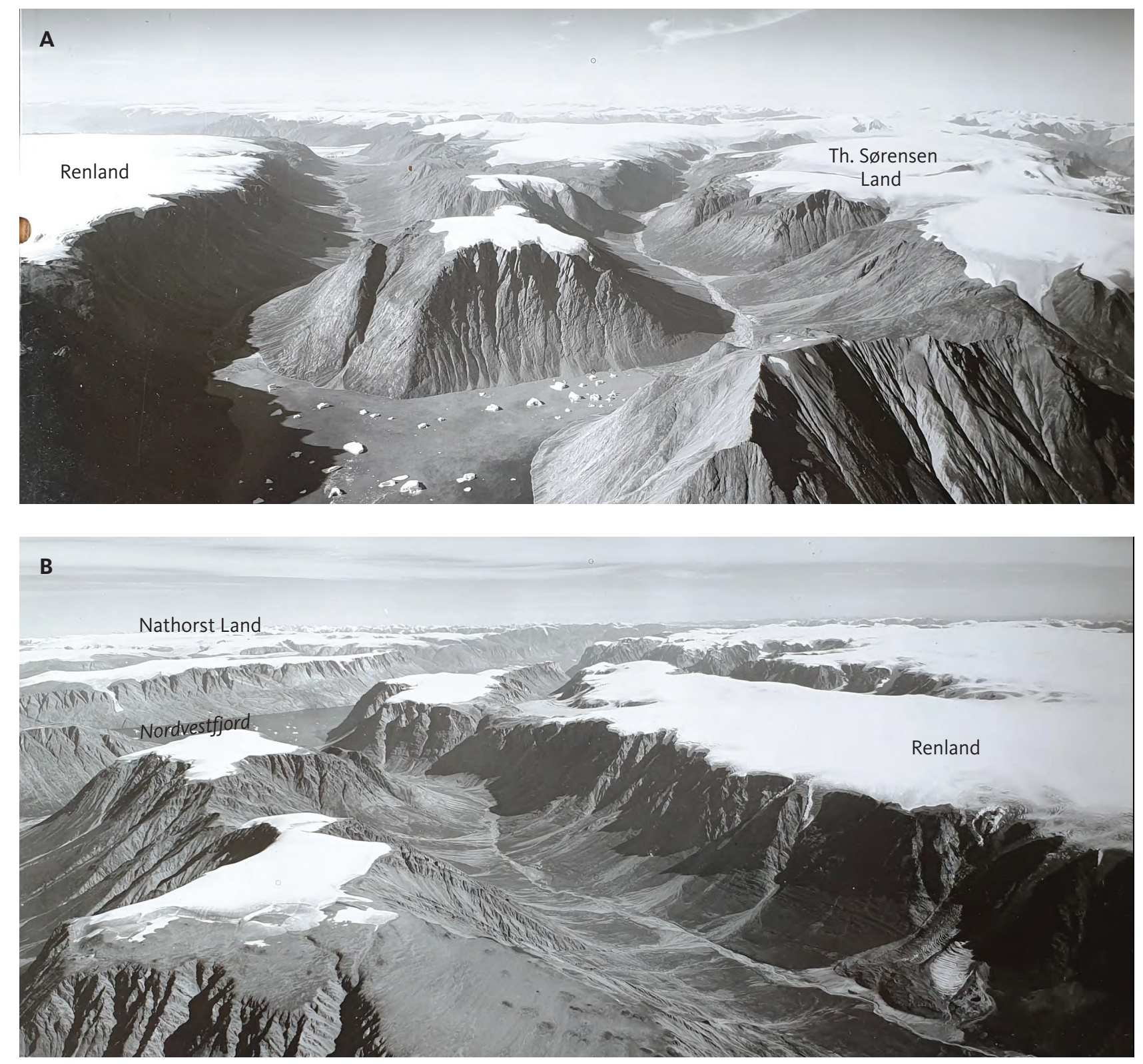

Fig. 13 The Upper Planation Surface (UPS) developed across basement rocks in the south-western interior of North-East Greenland: A: Looking south-west of Th. Sørensen Land and Renland across Nordvestfjord. B: Looking north-east from Renland towards Nordvestfjord and Nathorst Land. C: Looking south-west across the southern part of Stauning Alper towards Nordvestfjord and Renland. D: Looking south of Nathorst Land towards Furesø. Photo locations in Fig 9. Photo: Kort \& Matrikelstyrelsen, Denmark.

LPS are fluvial in origin, this also suggests that the LPS was completed prior to the onset of the major, late Cenozoic glaciations at c. 2.7 Ma. The incision of the LPS below the UPS and the wide areal extent of the LPS in the north suggest: (1) a change of base-level (uplift) after the formation of the UPS and (2) re-establishment of relatively stable tectonic conditions so that the planation surface could develop across a large area. This cycle of events was repeated as the LPS is also uplifted. The LPS must have formed during the late Neogene as it is younger than the UPS that had formed by mid-Miocene times.

\subsubsection{Amount of uplift}

We have shown that the UPS and the LPS were formed as erosion surfaces graded to former base level and therefore, their present elevation and the difference in elevation between them can be used to estimate the amount of uplift since their formation (Fig. 19). The vertical distance between these two surfaces represents the magnitude of the first post-UPS uplift event, allowing for subsequent erosion. The distance from the LPS to the present sea level represents the second post-UPS uplift event. This means that after the UPS was graded to base level, an uplift phase raised it to about $1 \mathrm{~km}$ 

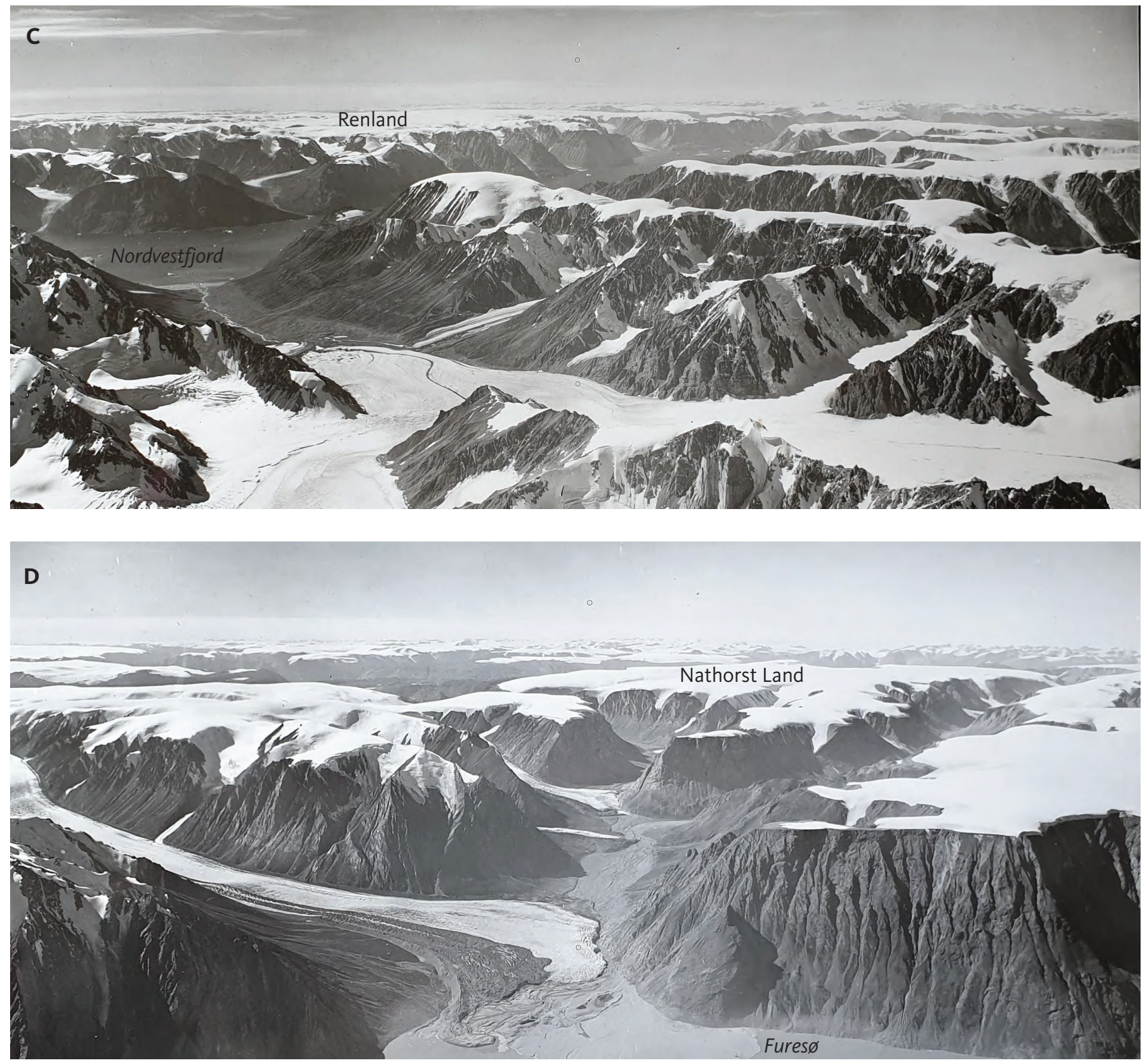

Fig. 13 (Continues) The Upper Planation Surface (UPS) developed across basement rocks in the south-western interior of North-East Greenland: A: Looking south-west of Th. Sørensen Land and Renland across Nordvestfjord. B: Looking north-east from Renland towards Nordvestfjord and Nathorst Land. C: Looking south-west across the southern part of Stauning Alper towards Nordvestfjord and Renland. D: Looking south of Nathorst Land towards Furesø. Photo locations in Fig 9. Photo: Kort \& Matrikelstyrelsen, Denmark.

a.s.l., leading to incision that graded the LPS to sea level. A subsequent uplift phase of $c .1 \mathrm{~km}$ raised the whole landscape, leaving the LPS at about $1 \mathrm{~km}$ a.s.l. However, in the northernmost parts of the study area the LPS did not reach such heights, for example, $600 \mathrm{~m}$ on Germania Land. These two uplift events define the main appearance of the present-day topography in NorthEast Greenland.

\subsubsection{Relative denudation chronology}

Based on the mapping of the planation surfaces and the identification of re-exposed surfaces combined with the geological record, we propose the following relative denudation chronology for North-East Greenland.
Denudation and weathering of the basement in pre-Middle Jurassic and pre-Eocene times led to the formation of deeply weathered basement surfaces characterised by a hilly relief. The extrusion of Palaeogene basalts during the break-up of the North-East Atlantic was accompanied by rapid subsidence (e.g. Brooks 1985, 2011; Larsen et al. 1989).

The first uplift phase in post-basalt times was accompanied by erosion to the new base level, resulting in the formation of the UPS as a regional denudation surface that cuts across the Palaeogene basalts and older rocks. This phase most likely happened around the EoceneOligocene transition when uplift of the inner margin of South-East Greenland triggered a sudden and strong 

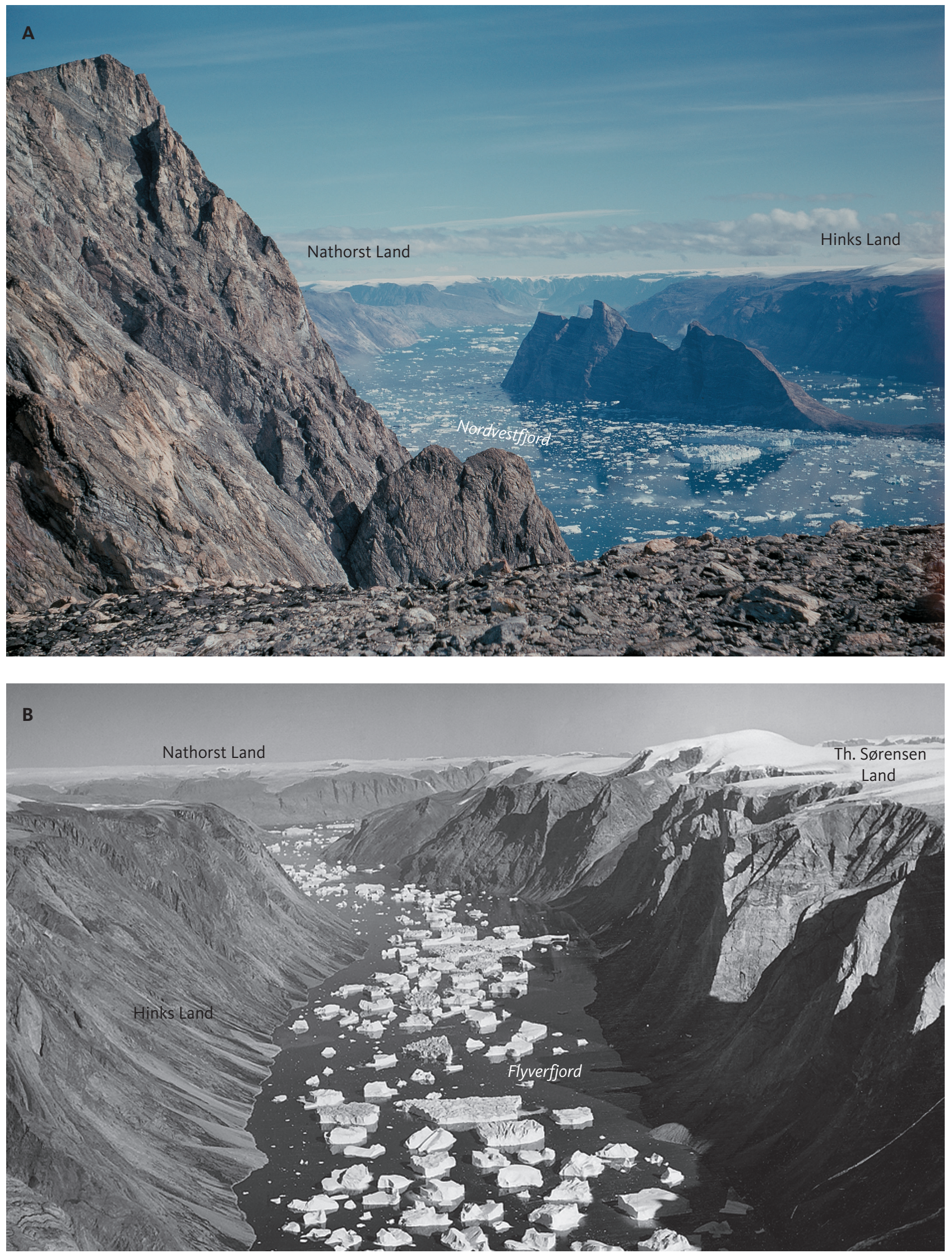

Fig. 14 Thin ice covers the Upper Planation Surface (UPS) in many locations in North-East Greenland: A: View along Nordvestfjord towards the south-east. B: The east-west-trending Flyverfjord. North is to the left of the image. C: Looking west along the inner part of Kejser Franz Joseph Fjord towards Andrée Land. D: View from Milne Land towards the south across Scoresby Sund where the UPS defines the top of the basalts on Geikie Plateau. Photo locations in Fig. 9. Photos A-C: GEUS archive. 

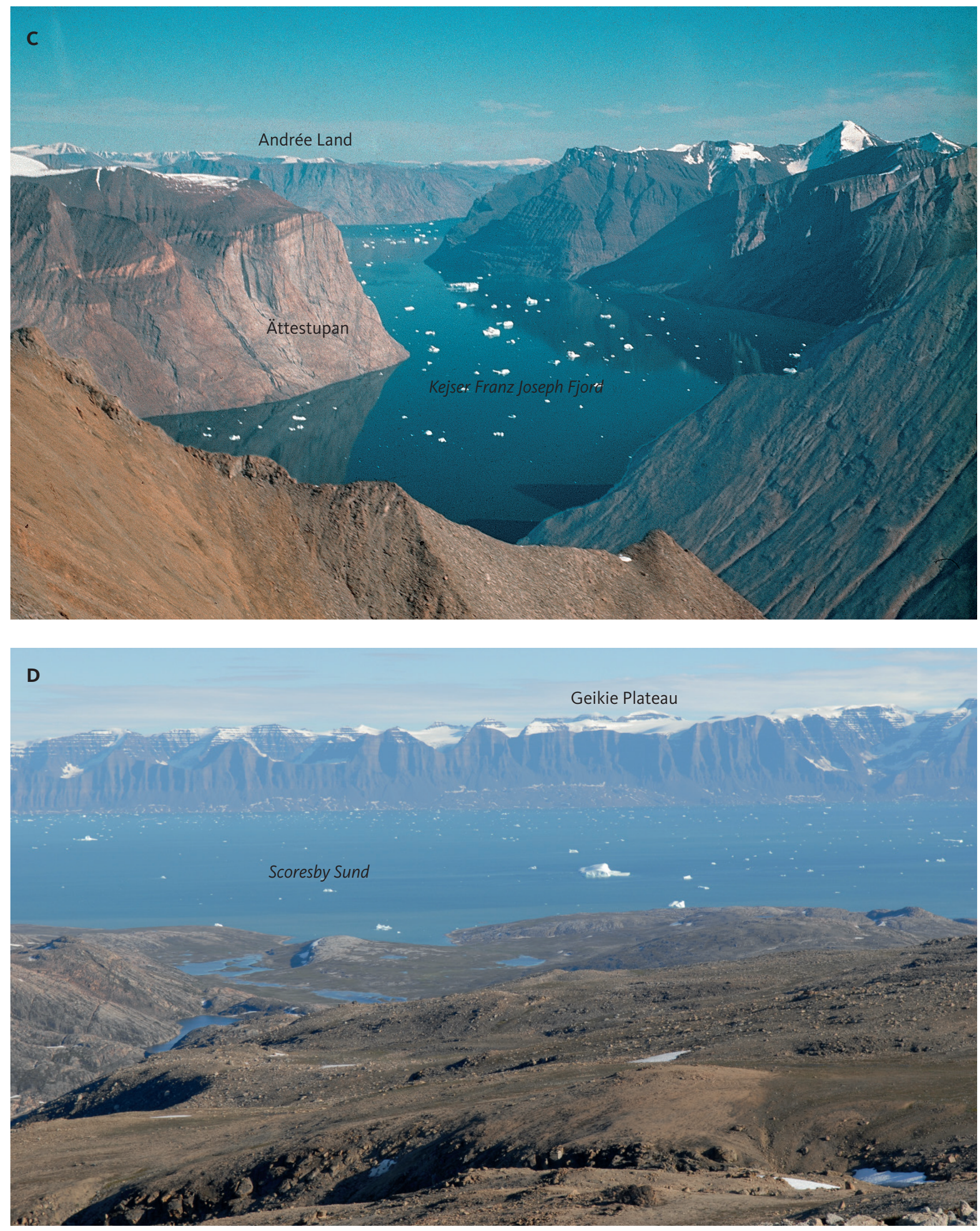

Fig. 14 (Continues) Thin ice covers the Upper Planation Surface (UPS) in many locations in North-East Greenland: A: View along Nordvestfjord towards the south-east. B: The east-west-trending Flyverfjord. North is to the left of the image. C: Looking west along the inner part of Kejser Franz Joseph Fjord towards Andrée Land. D: View from Milne Land towards the south across Scoresby Sund where the UPS defines the top of the basalts on Geikie Plateau. Photo locations in Fig. 9. Photos A-C: GEUS archive. 

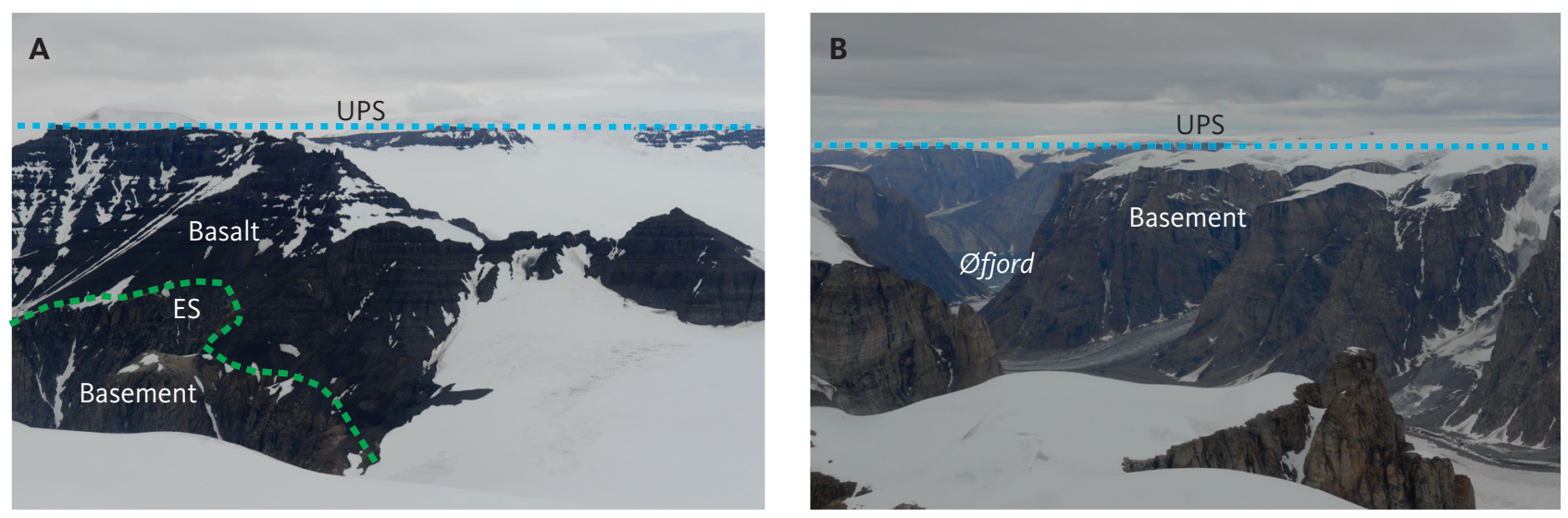

Fig. 15 The Upper Planation Surface (UPS) developed at an elevation of about 1800 a.s.l. across Palaeogene basalt and basement on Milne Land, constraining the age of the UPS to be younger than the Palaeogene basalts. A: UPS cutting across the basalt. ES: etch surface. B: UPS cutting across basement, note Øfjord in the background. There are only a few kilometres between the two locations. Photo locations in Fig. 9.
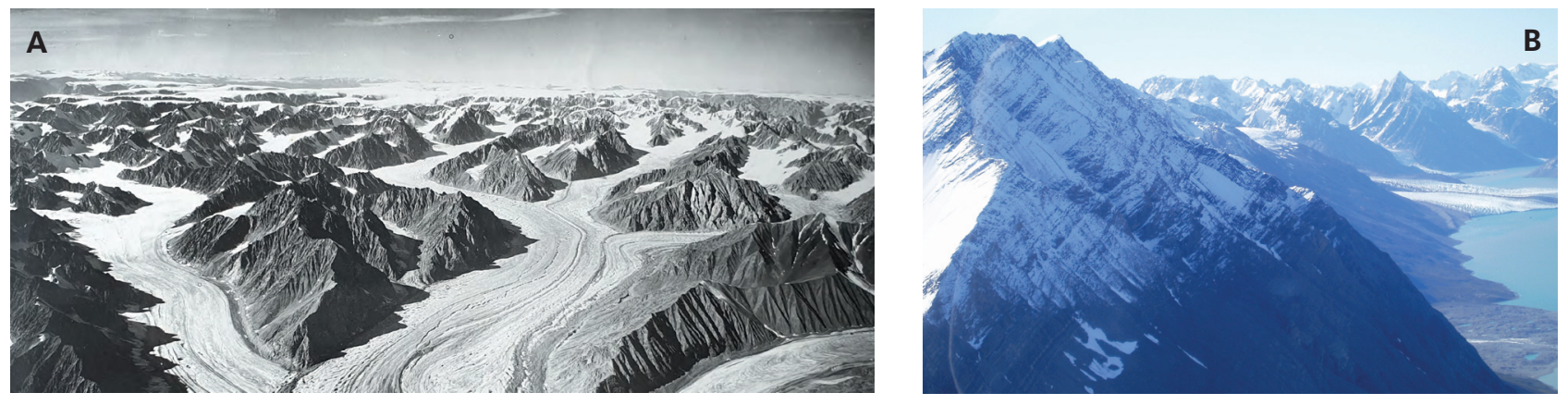

C

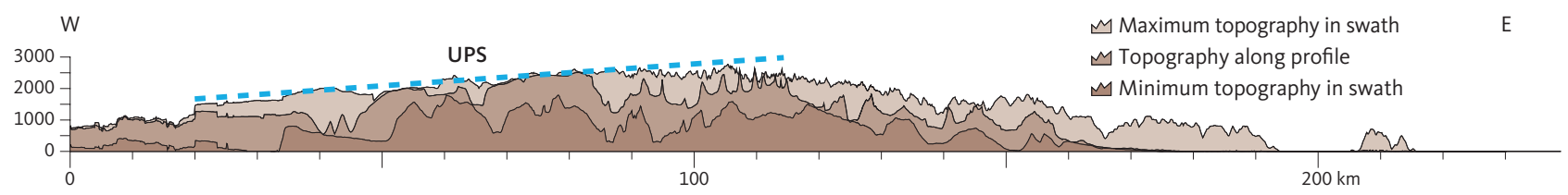

Fig. 16 Topography across Stauning Alper: A, B: Landscape with alpine relief and no remnants of the Upper Planation Surface (UPS) across Stauning Alper. Note that the UPS is present towards the north-west in the background of panel A. Photo A: GEUS archive. Photo B: Mette Olivarius. C: W-E profile illustrating that the peaks of the alpine relief can be projected to a surface (blue dashed line) that is coherent in the west. X-axis: UTM easting $(\mathrm{km})$. Y-axis: Elevation (m). Locations in Fig. 9.

influx of coarse, clastic turbidites offshore. These turbidites overlay fine-grained lower Eocene sediments (Larsen et al. 1994b; Bonow et al. 2014). When this planation surface had finally formed, it had a low topographical expression in the landscape, graded to near the base level at that time, which must have been the adjacent Atlantic Ocean. The presence of the mid-Miocene Vindtop Formation above the Palaeogene basalts just south of our study area, implies that the UPS had formed by mid-Miocene times and thus well before the onset of glaciation (Bonow et al. 2014). Glacial cirques and valleys cutting into the UPS also support this observation.

The development of the UPS was terminated by a second, post-basalt uplift phase that raised the landscape by about $1 \mathrm{~km}$. This led to incision of valleys below the uplifted UPS and to the development of a new surface, the LPS, during the late Neogene as it is younger than the UPS that had formed by mid-Miocene times.

The development of the LPS was terminated by a third base level change in post-basalt time, due to uplift of the landscape by about $1 \mathrm{~km}$, which then led to dissection of the LPS. The further destruction of both the UPS and LPS was partly glacial and occurred during the late Cenozoic glaciations.

\section{Discussion}

\subsection{Does present-day topography reflect the pre-break-up landscape?}

New mapping of Traill $\varnothing$ and Geographical Society $\varnothing$ indicates three main rift phases during the Devonian-Triassic, 


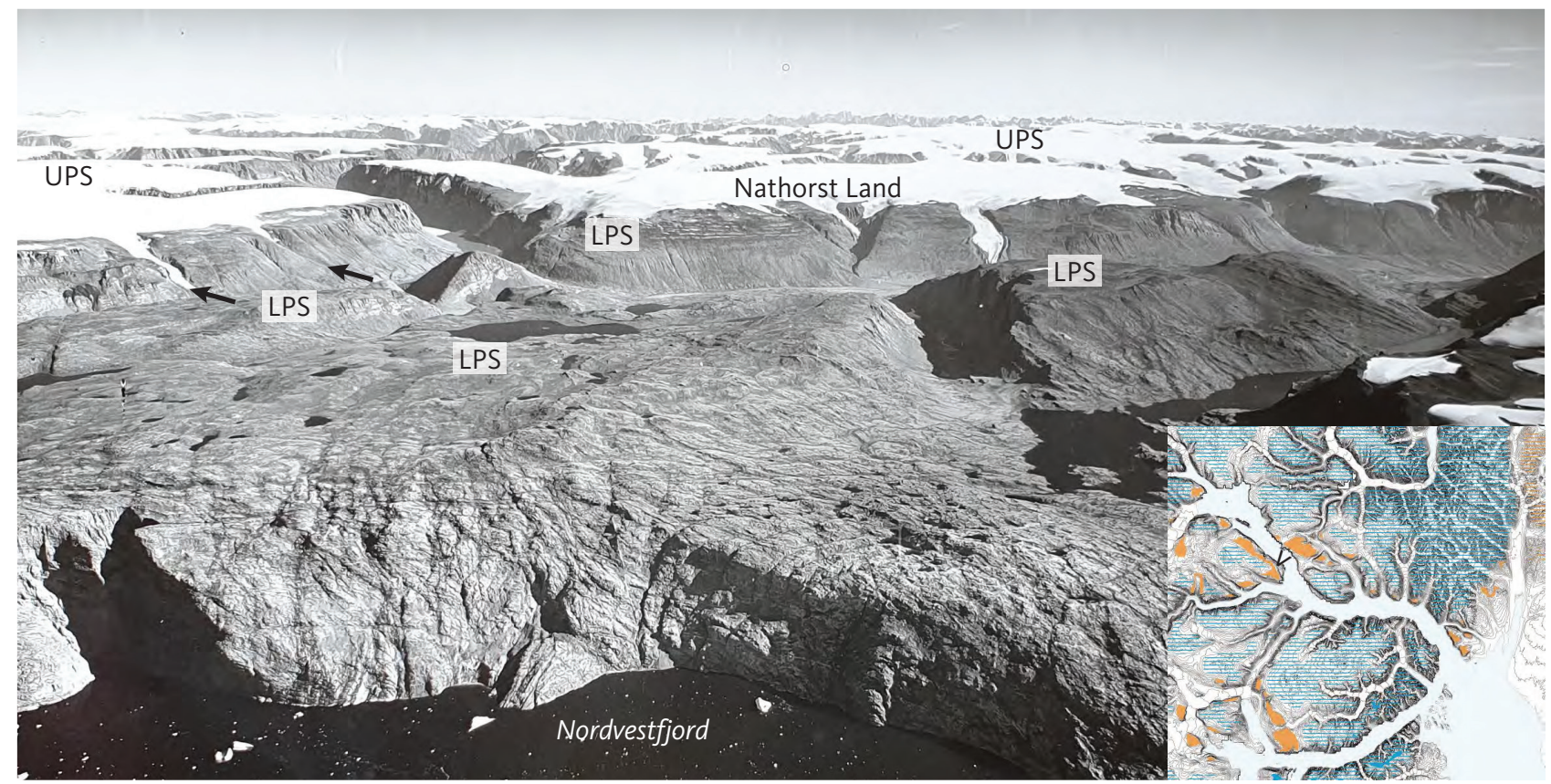

Fig. 17 Relationship between the Upper and Lower Planation Surface (UPS and the LPS, respectively) along the north side of Nordvestfjord: LPS is well developed on the north side of Nordvestfjord and there is a distinct escarpment towards the UPS that is well developed across Nathorst Land. Note the consistent level of the LPS and that minor valleys often stop incising at that valley bench (black arrows). The inset map shows the photo location and the detailed mapping of the UPS (blue) and the LPS (orange) in the area, see supplementary file S1. Photo: Kort \& Matrikelstyrelsen, Denmark.

Jurassic-Cretaceous and Palaeogene with the greatest amounts of faulting and block rotation occurring during the latter phase related to break-up of the North Atlantic c. $56 \mathrm{Ma}$ and to the plate reorganisation c. $36 \mathrm{Ma}$ (Parsons et al. 2017). The cross sections published by Parsons et al. (2017; fig. 10) show no correlation between the present-day landscape and the underlying Mesozoic sediments and the fault systems that offset them. This lack of correlation agrees well with our identification of the LPS in the summits over large parts of Traill $\varnothing$ and Geographical Society $\varnothing$ (Fig. 7B). As argued in Section 5.2.1, the LPS was likely graded to the base level in the late Neogene, and it is therefore significantly younger than the dominant Palaeogene phase of block rotation. Consequently, faulting prior to, during, or after break-up has left few traces in the present-day landscape.

Swift et al. (2008) found the first-order topography in North-East Greenland to be closely related to the main aspects of the regional geology, in particular, controlled by escarpments along major geological boundaries. They also used the configuration of the pre-basalt surface from a small area in Milne Land in relation to the post-Devonian Main Fault system to argue that the present first-order topography had existed since at least the time of break-up, c. 55 Ma. Swift et al. (2008) did not, however, consider Ahlmann's (1941) conclusion that the first-order topography must have developed in post-basalt time, following the observation that planation had occurred across both Palaeogene basalts and basement rocks to form the continuous erosion surface on a regional scale, which is now present as an elevated plateau (the UPS). The detailed mapping presented here also shows that there is no change in the separation between the UPS and LPS across the post-Devonian Main Fault system, so the fault does not control the development of the first-order topography. Instead, the step (escarpment) between the two surfaces winds along the main valleys that cut across the fault system (Fig. 7B). Geological evidence from the Blosseville Kyst region (Nielsen et al. 1981) further shows that the flood basalts were extruded near sea level and the kilometre-scale subsidence kept pace with the extrusion of the basalts (see Bonow et al. 2014 and references therein). The presence of late Paleocene to earliest Eocene marine strata at elevations up to $700 \mathrm{~m}$ a.s.I. on Wollaston Forland, Hold with Hope and Sabine $\varnothing$ (Nøhr-Hansen et al. 2011), demonstrates that the present-day landscape and topography is very different from the landscape at the time of continental break-up. Furthermore, these observations document that post break-up rock-uplift was at least $700 \mathrm{~m}$, which is in agreement with the elevation of the LPS in this region of about $1 \mathrm{~km}$. However, possible post-rift burial of the marine sediments would lead to a bigger magnitude of their vertical movement since maximum burial.

Pedersen et al. (2012) presented a different view on the origin of the present-day mountains in North-East Greenland. They suggested that the mountains represent remnants of the original Caledonian topography 

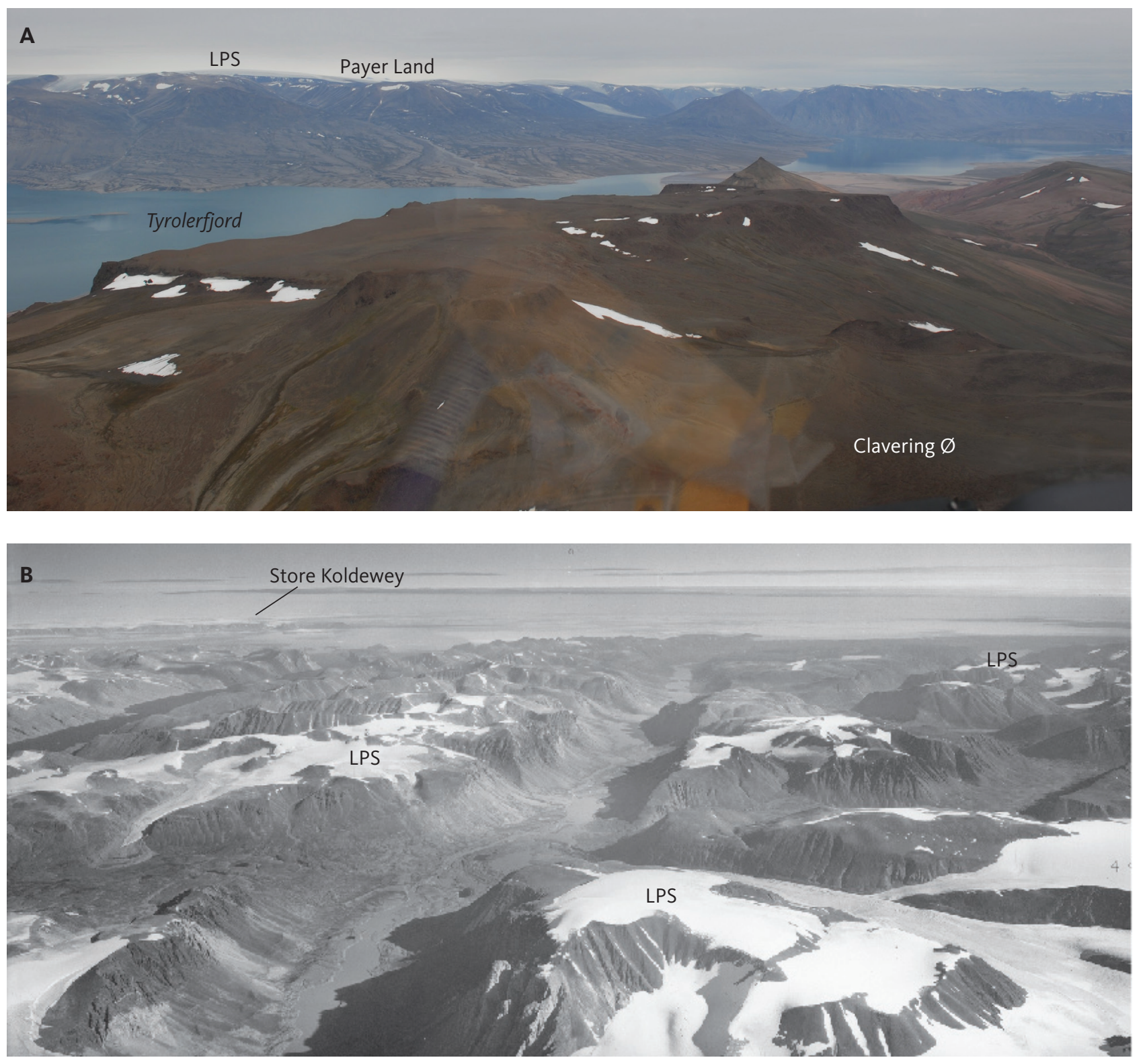

Fig. 18 The Lower Planation Surface (LPS) in the northern part of the study area: A: View of the LPS at c. $1300 \mathrm{~m}$ a.s.I. on Payer Land seen from Clavering $\varnothing$ towards the north-west across Tyrolerfjord. Minor remnants of flattish land in the foreground are interpreted as the LPS developed in sedimentary cover rocks. The extensive surface in the background formed across crystalline basement. Photo: GEUS archive. B: View east, overlooking basement terrain in Dronning Margrethe II Land with Store Koldewey in the background. The flat summits are interpreted to be part of the LPS and are c. 1 km a.s.l. Photo: Kort \& Matrikelstyrelsen, Denmark. Photo locations in Fig. 9.

modified during early rifting and that the area has undergone slow, steady exhumation since c. $250 \mathrm{Ma}$. They based this hypothesis on inverse modelling calibrated by AFTA data from samples of exposed Caledonian basement. However, AFTA data on their own register only episodes of cooling and must be integrated with geological evidence to reveal episodes of reheating that reflect re-burial. The modelling results of Pedersen et al. (2012) are at odds with the observations presented here that show two elevated plateaus, formed and uplifted after break-up, dominate the landscape of North-East Greenland. Japsen et al. (2013) described how the well-documented geological record of North-East Greenland (e.g. Surlyk 1990) shows that the Caledonian mountains were obliterated as topographic features during the late Palaeozoic. The presence of outliers of both Upper Carboniferous and Middle Jurassic sediments resting on the basement in the study area of Pedersen et al. (2012) also provides evidence of a history involving episodic, post-Caledonian exhumation and re-burial. Japsen et al. (2013) concluded that the geological record in East Greenland is 


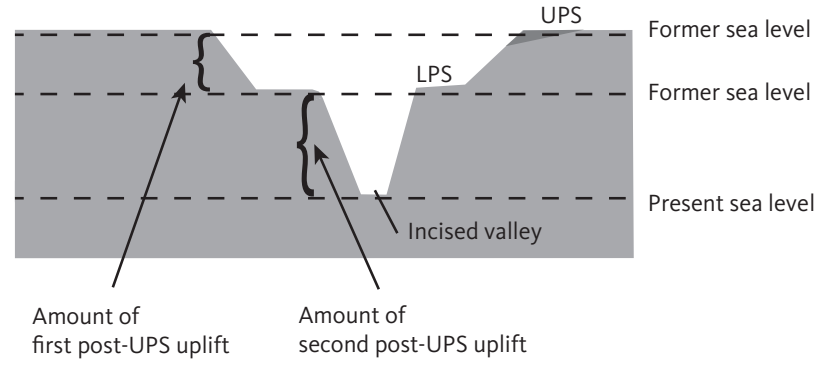

Fig. 19 Conceptual model that demonstrates how to estimate the amount of uplift based on the elevation of peneplains and their relationship to the base level. UPS: Upper Planation Surface. LPS: Lower Planation Surface.

incompatible with the idea of slow, steady exhumation since the Caledonian orogeny.

\subsection{Formation and preservation of surfaces}

The characteristic basement hills, separated by minor valleys, which frequently appear below the Palaeogene basalts, are the result of erosion during different weathering episodes in the Mesozoic (Larsen et al. 1989). At that time, the basement was exposed on the Earth's surface and became deeply weathered, forming saprolites, under warm, humid conditions. Stripping of saprolites occurred during drier conditions. After its formation and until recently, this weathered basement surface (ES) and the saprolites must have been protected from erosion by a cover of sediments or basalts, as seen in the area around Milne Land. Whereas the basement areas at high elevation are planated and typically form part of the UPS, the characteristic hilly relief of the ES occurs only at low elevation. The ES must have been covered when the planation occurred, otherwise this relief would have been obliterated by the planation (Figs 3, 11), which suggests a recent episode of exhumation due to late uplift. A similar history with Mesozoic deep weathering, followed by burial and late Cenozoic exhumation, has also been documented in West Greenland (Bonow 2005), southern Greenland (Peulvast et al. 2011) and Scandinavia (Lidmar-Bergström 1988, 1989; Lidmar-Bergström et al. 2017).

The UPS is preserved mainly in areas with resistant rocks such as crystalline basement and Palaeogene basalts (e.g. on Gåseland and Milne Land; Fig. 12). There are only minor remnants of the UPS in coastal areas underlain by sedimentary sequences, for example on Traill $\varnothing$. Prior to the first uplift of the UPS, the surface most likely extended across a much wider area towards the coast, across the sedimentary basins on Jameson Land, for example.

Independent lines of evidence support the suggestion that the UPS once covered a much wider area towards the coast. Palaeogene volcanics are present offshore between $72^{\circ} \mathrm{N}$ and $76^{\circ} \mathrm{N}$ (Henriksen et al.
2009), and it is thus likely that a thick cover of basalts was present in the coastal zone of the study area, where the basalts occur as outliers today (Fig. 4), and across Jameson Land (Mathiesen et al. 2000). By inference, it is likely that the UPS developed across this now-lost, basalt cover. Similarly, a late Palaeogene unconformity mapped on seismic sections across the Jan Mayen micro-continent (around $68^{\circ} \mathrm{N}, 12^{\circ} \mathrm{W}$ ), has been suggested as an equivalent of the UPS onshore in East Greenland (Blischke et al. 2019).

While the UPS is preserved mainly in resistant rocks, the preservation pattern of the LPS is different (Fig. 7B). In the south, the LPS is mostly preserved as a coherent surface in areas with sedimentary rocks. In areas with crystalline basement, in the south-western part of the study area, for example, the LPS is identified as valley shoulders within the major valleys below the UPS. In the north, the LPS is developed as a coherent surface across a crystalline basement around Dove Bugt, for example. The LPS thus appears to have developed across the entire study area as an extensive plain in coastal areas and as the floor of fluvial valleys incised below the UPS in the hinterland.

The preservation pattern thus indicates that both the UPS and the LPS were destroyed quickly when formed across the sedimentary basin, but they have been preserved to a large degree where they formed across basement rocks, or basalts. We thus conclude that, once a large-scale surface has formed across resistant rocks like crystalline basement, it will persist and dominate the topography for a long time and is not easily reshaped (Brunsden 1993). The primary destruction of a peneplain thus occurs along the edge of valleys that were formed after uplift of the peneplain. This erosional pattern is observed in other uplifted areas (Liu et al. 2019).

The effect of glacial erosion on elevated plateaus covered by cold-based ice is limited, while significant erosion occurs in the deeply incised valleys (e.g. Sugden 1974; Bonow et al. 2006b; Swift et al. 2008; Hall et al. 2013a; Cook et al. 2020). Consequently, glacial erosion will lead to an increased relative relief between the comparatively unaffected pre-glacial peneplains and the glacial incision focussed in the valleys (Johansson et al. 2001; Hall et al. 2013a), whereas isostatic rebound due to fluvial and glacial erosion will increase the overall elevation of uplifted landscapes (Medvedev et al. 2013).

\subsection{Two-stepped surfaces or one arched surface?}

The geomorphological work by Ahlmann (1941) was a major achievement based as it was, on poor maps, limited fieldwork and some aerial photographs. Ahlmann (1941) was of the opinion that the landscape in NorthEast Greenland consisted of just one erosion surface (the 

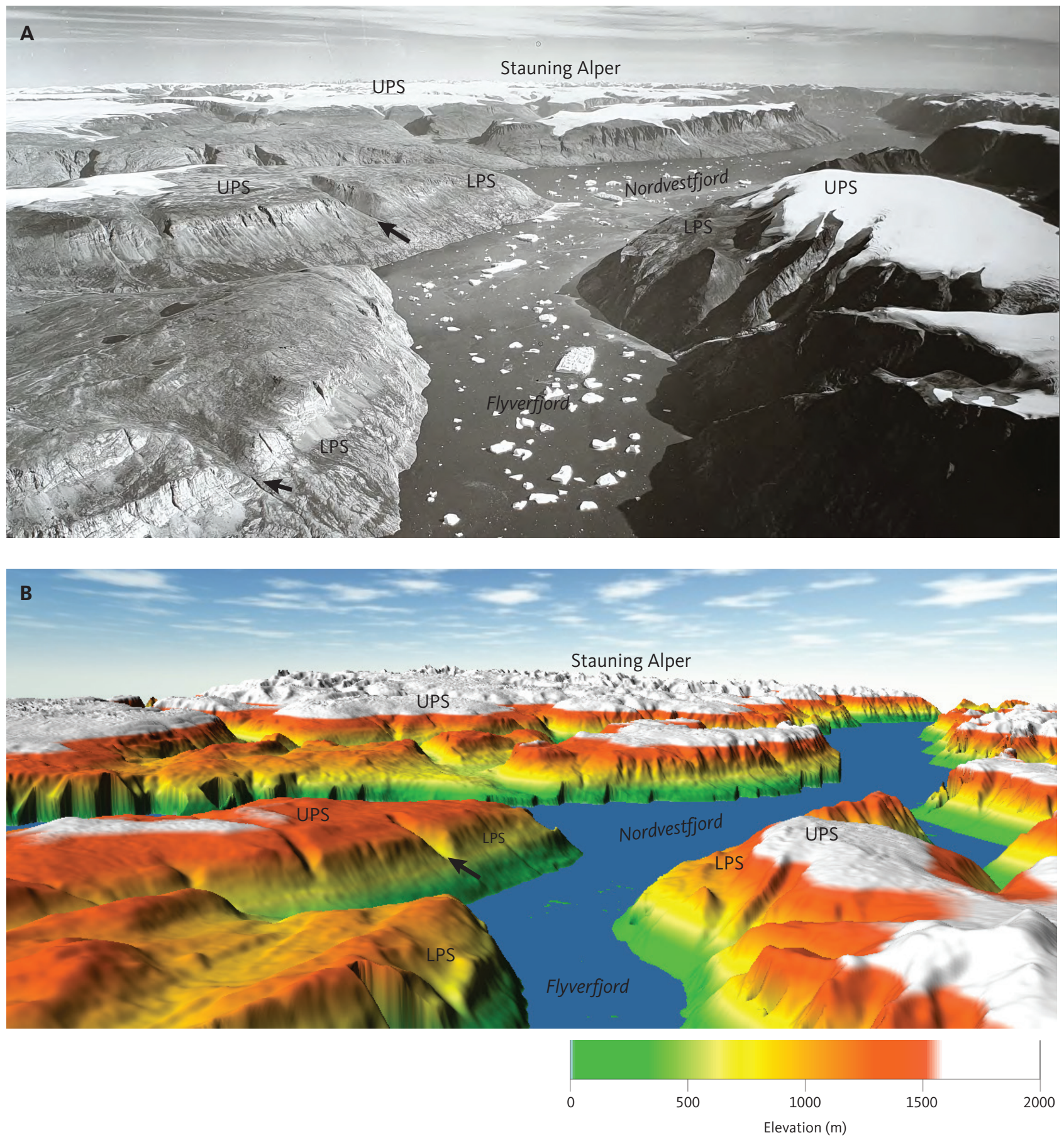

Fig. 20 The incision of the LPS into the UPS as a valley bench along Nordvestfjord (Lower and Upper Planation Surface, respectively): A: LPS along Flyverfjord and Nordvestfjord; view north-east across Th. Sørensen Land towards Nathorst Land (UPS) and Stauning Alper. B: 3D elevation model from ASTER data in approximately the same area. The LPS is developed as valley benches along the main fjords. Minor valleys connect the UPS with the LPS (black arrows). Map location in Fig. 9.

'initial topography' as he referred to it, which generally corresponds to the UPS of the current study). He regarded this surface to be arched towards the present-day coast.

In contrast, we find that the large-scale landscape in North-East Greenland consists of two distinct surfaces with a distinct step between them and not the single arched surface that Ahlmann described. Where the UPS and LPS overlap, there is a step between them.
This step is not formed by a fault or fracture system (e.g. the Post-Devonian Main Fault system); rather, it occurs where the sides of the valleys incised to form the LPS. This provides further evidence that the step is erosional. Stepped surface landscapes with similar forms are also present along other passive margins in central West Greenland (Bonow et al. 2006b), Norway (Lidmar-Bergström et al. 2000; Bonow et al. 2003), 
Brazil (Peulvast \& Claudino Sales 2004), southern Africa (King 1967; Green et al. 2017) and Ethiopia (Coltorti et al. 2007).

\subsection{The domal structure of the UPS around Stauning Alper}

Ahlmann (1941) identified a dome structure for the 'initial topography' with the highest elevation occurring around Stauning Alper. This feature corresponds to the anticlinal structure of the UPS identified on profiles for the area in this study (Fig. 16). Stauning Alper exhibits a significant alpine relief and is one of the most dissected areas in North-East Greenland. This type of relief is probably not due to a specific rock type because similar crystalline rocks occur in nearby areas at lower elevation where the UPS is very well preserved (e.g. Renland, Milne Land; Figs 13, 20). It thus seems likely that Stauning Alper has a tectonic history that deviates from the regional pattern after the formation of the UPS because the area experienced more uplift and perhaps, earlier uplift than the surrounding areas. Such development would inevitably lead to valley incision and relief rejuvenation, and possibly more erosion by cirque and valley glaciers, which would obliterate the UPS.

\subsection{Comparison with erosion surfaces in West Greenland}

The landscape of central West Greenland shares characteristics with that of North-East Greenland. A weathered basement surface has been identified in and around the Nuussuaq Basin (Pulvertaft \& Larsen 2002; Bonow 2005). This surface is of Cretaceous to Paleocene age and is characterised by distinct hills and kaolinitic saprolites (Bonow 2005). Bonow et al. (2006b) mapped the weathered basement surface south of the Nuussuaq Basin and demonstrated that it is cut off by a post-basalt planation surface (also labelled UPS). The final formation age for the weathered surface in West Greenland is similar to the Palaeogene, sub-basalt, ES in North-East Greenland, which indicates that the weathering reflects a large-scale erosion event.

The main, post-basalt peneplain (the UPS) in central West Greenland has similar characteristics to the UPS in North-East Greenland (Bonow et al. 2006a, 2006b). However, whereas the UPS in North-East Greenland is also preserved in areas with less resistant basalts (e.g. Milne Land), the equivalent UPS in West Greenland is mainly preserved in basement rocks and is deeply dissected in the basalt areas on Nuussuaq and Disko (Bonow et al. 2006a). The UPS in North-East Greenland is located at a significantly higher elevation and is less tilted than that in West Greenland. The West Greenland UPS is also divided into several tectonic blocks that dip in different directions, while the North-East Greenland UPS is folded only around Stauning Alper. The high elevation together with less tilting and rotation might explain why the UPS is better preserved and thus of a wider extent in NorthEast Greenland.

The LPS in North-East Greenland is present across a significantly wider area than the equivalent surface in West Greenland, where it forms only a partially developed surface along a few valleys (Bonow et al. 2006b). One possible explanation could be that block movements and tilting have disrupted surface development in West Greenland (Bonow et al. 2006b), while the uplifts in North-East Greenland apparently have a more regional character. The LPS in West Greenland was also probably developed across Cretaceous sediments and Palaeogene basalts in the Nuussuaq Basin, where the surface was later obliterated by erosion.

\subsection{The formation of the LPS and the onset of glacial conditions in Greenland}

There is evidence of glacial activity from c. 7 Ma off East Greenland in the form of ice-rafted debris in Ocean Drilling Program (ODP) boreholes, which suggest that full glacial conditions were established in South-East Greenland by that time (c. $63^{\circ} \mathrm{N}$ and $70.5^{\circ} \mathrm{N}$; Larsen et al. 1994b; Jansen et al. 1996; Channell et al. 1999). Recently, Pérez et al. (2018) inferred that cross-shelf glaciation off Blosseville Kyst and Liverpool Land began to influence the shelf during the deposition of upper Miocene to lower Pliocene sediments (7.3-4.9 Ma) based on seismic data tied to ODP borehole 987, off Scoresby Sund. For example, they attributed the prograding character of this succession, as well as the shift in depocentre configurations from inner to middle and outer shelf, to ice advancing across the shelf off Blosseville Kyst. In particular, they attributed outward-bulges in the depositional pattern to active ice streams crossing the continental shelf, in contrast to a previous study that inferred dominantly hemipelagic origin of late Miocene deposits off Scoresby Sund (Butt et al. 2001). However, according to Pérez et al. (2018), the two major phases of ice-sheet advance occurred after the Miocene - in the early Pliocene and around the Pliocene-Pleistocene transition (at c. $5 \mathrm{Ma}$ and between 2.9 and $2.3 \mathrm{Ma}$, respectively).

Further insight into the glacial history of East Greenland may be obtained from the stratigraphic landscape analysis in East Greenland $\left(68-78^{\circ} \mathrm{N}\right)$ presented here, and by Bonow et al. (2014). The formation of the LPS by incision below the UPS is thought to be controlled by the fluvial system because the LPS extends at the same elevation from the valley benches in the interior to the plateau remnants across the sedimentary basins closer to the coast (Figs 7B, 9A, 20). This observation implies that full glacial conditions were not established during 
the formation of the LPS. The LPS must have formed during the late Neogene because it is younger than the UPS, which had been formed by the mid-Miocene. This interpretation is supported by the integration of stratigraphic landscape analysis with AFTA data in southern East Greenland, which led to the following conclusions (Japsen et al. 2014):

1. Late Miocene uplift (c. $10 \mathrm{Ma}$ ) led to the onset of incision of the LPS below the UPS

2. Early Pliocene uplift (c. $5 \mathrm{Ma}$ ) led to the incision of valleys and fjords below the LPS.

This timeframe is further supported by AFTA data in NorthEast Greenland (Japsen et al. in press). The LPS was thus established by the fluvial system in the interval between 10 and $5 \mathrm{Ma}$; thus, it is unlikely that full glacial conditions were established in East Greenland at this time.

We therefore suggest that the fluvial system led to the expansion of the shelf during the late Miocene; for example, along Blosseville Kyst. We note that over-deepened troughs were not observed across the shelf in the corresponding succession (unit 7) on the seismic lines presented by Pérez et al. (2018), whereas major ice streams would have created such troughs. This indicates that glacial action prior to the Pliocene was restricted to valley glaciers, which led to deposition of ice-rafted debris offshore, similar to the valley glaciers of Greenland reaching the sea today. The prograding character of the upper Miocene succession, as well as the shift in depocentre configuration off Blosseville Kyst at this time, may be the result of glacio-fluvial deposition. The major phases of ice-sheet advance and full glacial conditions thus only occurred after the Miocene (Solgaard et al. 2013; Pérez et al. 2018), in agreement with our conclusion that the final phase of uplift took place in the early Pliocene (Japsen et al. 2014).

\subsection{Plateau landscapes are not related to glaciation}

The presence of mid-Miocene volcanics on the UPS just south of the study area demonstrates that the UPS was formed prior to the onset of large-scale Neogene glaciations in Greenland (Larsen et al. 1994b; Storey et al. 2004; Bonow et al. 2014). As discussed in the previous section, the LPS is the result of late Neogene fluvial incision to below the UPS. The incision likely occurred prior to uplift in the early Pliocene and was followed by the major phases of ice-sheet advance and full glacial conditions. The UPS and the LPS are therefore not considered glacial surfaces, but their destruction was partly glacial as illustrated by the glacial forms that cut into them.

Our results agree with the well-established observation that old landscapes, sometime called 'relict surfaces' are preserved beneath non-erosive, cold-based ice (Kleman 1994; Kleman \& Hättestrand 1999; Sugden et al. 2005; Kleman 2008; Ebert \& Hättestrand 2010; Hall et al. 2013a, 2013b). However, in terrains of selective linear glacial erosion, wet-based ice behaves differently. In hilly relief terrain, wet-based glaciers exploit and enhance the pre-glacial relief (e.g. Sugden 1974) while flat surfaces (e.g. planated surfaces) are not significantly altered (Lidmar-Bergström 1997; Johansson et al. 2001). In North-East Greenland, the elevated and flat terrain has facilitated the formation of cold-based ice, even in coastal areas on Store Koldewey, for example, where the flat basement summits are unscoured (Håkansson et al. 2007). Alpine relief mainly developed along the coast at Stauning Alper, for example. Similar patterns have been observed in the Blosseville Kyst region (Bonow et al. 2014).

Braun (2018) argued for the apparent longevity of high-elevation passive margins based on numerical modelling. Based on computational experiments, Egholm et al. (2017) proposed that plateau landscapes on glaciated margins reflected glacial and periglacial smoothing of an already elevated terrain prior to the inception of glaciers. Conclusions from such calculations and modelling are at odds with the results presented here, which document that the extensive plains in East Greenland were graded to sea level prior to the glaciations. The suggestion that glaciers produce smooth landscapes at high elevation is also at odds with modern understanding of glacial dynamics (e.g. Kleman et al. 2008; Hall \& Kleman 2014; Cook et al. 2020). Finally, the presence of two regional peneplains separated by a major step in the landscape is not explained by the models of Egholm et al. (2017). A part of the youngest uplift that produced the second major step in the landscape between the LPS and present-day sea level can be explained by glacial processes (Medvedev et al. 2013), but isostatic rebound caused by glacial carving cannot produce a two-stepped landscape. We therefore interpret these steps as manifestations of episodes of tectonic uplift that affected North-East Greenland during the late Neogene. High-level plateaus and deeply incised valleys are characteristic of EPCM around the world in both tropical and Arctic climates (Jessen 1943; King 1967; Japsen et al. 2012a; Green et al. 2013, 2018). Lidmar-Bergström et al. (2000) showed that major landscape features such as high plateaus, a great escarpment and a coastal plain are similar in character in both southern Norway and eastern Australia. Thus, the formation of elevated plateaus along passive continental margins is not necessarily related to glacial action.

The evidence presented here for the origin and age of the large-scale landscape in North-East Greenland is therefore a typical example of the development of an EPCM. 


\subsection{Neogene uplift and the formation of the Greenland ice sheet}

Solgaard et al. (2013) investigated the effects of two phases of Neogene uplift in both West and East Greenland, on ice sheet initiation using an ice sheet model in combination with a climate model. The uplift scenario tested in that study is similar to that defined by the presence of a landscape in two steps in North-East Greenland but put into an absolute timeframe based on AFTA data from West and East Greenland Japsen et al. 2006, 2014). The scenario supposes that the landscape was at a low level prior to the late Miocene, after which two phases of kilometre-scale uplift in the late Miocene and latest Miocene - Pliocene (beginning c. 10 and $5 \mathrm{Ma}$, respectively) initiated the formation of the present-day mountains. The landscape model of Solgaard et al. (2013) was based on stratigraphic landscape analysis in West and South-East Greenland (Bonow et al. 2006a, 2006b). The new results from North-East Greenland presented in this paper provide further support that the model is valid for Greenland in general.

The modelling results of Solgaard et al. (2013) showed that no ice could build up on the low-lying and almost flat landscape (defined by the UPS) prior to the first uplift ( $c$. $10 \mathrm{Ma}$ ). However, the models demonstrated significant ice expansion in response to increased precipitation and cooling due to the two phases of uplift that raised the UPS to its present elevation. Large amounts of ice could have formed after the first uplift event (leading to formation of the LPS), but the model showed that the ice sheet is sensitive to changes in climate. The second phase of uplift (c. $5 \mathrm{Ma}$, which led to the uplift of the LPS) facilitated the ice-sheet build-up and increased the stability of the ice sheet in the models. However, they also suggested a Föhn effect that inhibited ice-sheet expansion into the interior of Greenland and thus shifted the threshold of formation of the ice sheet towards colder temperatures. Under conditions that are colder than the present, the ice could overcome the Föhn effect flow into the interior and form a coherent ice sheet. The results thus indicated that the present-day Greenland ice sheet is a relict formed under colder conditions. Solgaard et al. (2013) concluded that the late Cenozoic mountain building in Greenland augmented the effects of the climatic deterioration leading to the Northern Hemisphere glaciations, and that without the second phase of uplift the Greenland ice sheet would have been more sensitive to the changes in climate over the past millions of years.

The modelling of Solgaard et al. (2013) is consistent with the observed climatic variability superimposed on the general cooling trend in the late Cenozoic, specifically the presence of ice-rafted debris in late Miocene deposits off South-East Greenland and evidence for mid-Pliocene warmth (Larsen et al. 1994a; Dowsett et al.
2010). The results are also consistent with the observation that large-scale glaciation in the circum-Atlantic region only occurred in the late Pliocene, and that the increase in land-ice volume occurred slowly and stepwise over the period from c. 3.5 Ma to 2.4 Ma (Thiede et al. 1998; Mudelsee \& Raymo 2005; Pérez et al. 2018).

Pedersen et al. (2019) used the concept of geophysical relief (Small \& Anderson 1998) to estimate fjord erosion and the subsequent flexural isostatic response to erosional unloading in North-East and North Greenland between Scoresby Sund $\left(70^{\circ} \mathrm{N}\right)$ and Independence Fjord $\left(82^{\circ} \mathrm{N}\right)$. They constrained the timing of erosion and isostatic uplift by marine sediments of late Pliocene - early Pleistocene age that are now exposed on land between 24 and 230 m a.s.l. (Feyling-Hanssen et al. 1983; Funder et al. 2001; Bennike et al. 2002, 2010). In this way, Pedersen et al. (2019) found that the Independence Fjord system formed since c. $2.5 \mathrm{Ma}$. In contrast, their results indicated that fjord formation in the outer parts of Scoresby Sund commenced before the Pleistocene, most likely in the late Miocene and continued throughout the Pleistocene by progressive, inland fjord formation. The results of Pedersen et al. (2019) demonstrate that the inception of the Greenland ice sheet began in the central parts of North-East Greenland before the Pleistocene and spread to North Greenland only at the onset of the Pleistocene and are thus in accordance with the model of Solgaard et al. (2013).

\section{Conclusions}

The large-scale landscape of North-East Greenland is similar to EPCM worldwide, characterised by upland plateaus dissected by deep valleys. The detailed mapping presented in this study reveals a landscape dominated by two regional erosion surfaces, the UPS and LPS at $c$. 2 and $1 \mathrm{~km}$ a.s.l., respectively, cut by deeply incised valleys. The UPS is a major surface at some distance from the coast, up to $200 \mathrm{~km}$ wide. In large areas north of $74^{\circ} \mathrm{N}$, the UPS disappears below the ice sheet. Maximum elevation of the UPS is found in Stauning Alper, where the surface is dome shaped.

The UPS has a low relative relief, a regional extent and cuts across bedrock of variable age and resistance, including crystalline basement and Palaeogene basalts that erupted during break-up of the north-East Atlantic. This shows that the UPS was graded to base level, and the most likely base level was the Atlantic Ocean after the cessation of the volcanic eruptions. Hence, the UPS is a post-basalt peneplain. Further, the UPS must have formed prior to the eruption of the mid-Miocene lavas that rest on the UPS just south of our study area.

A significant change of base level (uplift) terminated the development of the UPS, leading to fluvial incision of valleys and to rejuvenation of the relief. The change 
of base level must have been followed by a period of more stable base-level conditions, because the valleys widened and eventually formed a coastal plain near the base level at that time. Consequently, a new regional, low-relief peneplain - the LPS - formed. The LPS is readily identified in the interior parts of the study area, where it forms fluvial valley benches below the UPS at present day elevations of c. $1 \mathrm{~km}$ a.s.l. The presence of these well-developed valley benches shows that the LPS had formed prior to the onset of late Cenozoic glaciations. Towards the coast, the valley benches of the UPS merge to form a more coherent surface that extends across a $100-\mathrm{km}$ wide zone. Where sedimentary rocks crop out, the LPS is only defined by flat-topped summits, while in the areas of crystalline basement rocks the LPS is more extensive and less dissected. North of $74^{\circ} \mathrm{N}$, the LPS dominates the ice-free areas of the elevated plateau landscape in near-coastal areas, while the UPS further west is covered by the Greenland ice sheet.

A second phase of base-level lowering (uplift) caused the LPS to lose contact with the former base level, and thus the LPS was dissected by a new phase of valley incision and relief rejuvenation. The result was a landscape with distinct levels, manifested by a winding escarpment between the UPS and LPS. This stepped landscape later became glaciated and further eroded.

The LPS is defined on both sides of the post-Devonian Main Fault system at about the same elevation, and this further supports that the LPS was formed by the fluvial system. The escarpment between the UPS and the LPS does not coincide with the fault system, which appears as a marked scarp in the terrain, defining the western boundary of the sedimentary basin system.

Each of the uplift events that affected the region after the UPS was graded to sea level, were in the order of $1 \mathrm{~km}$ and the UPS is now at an elevation of c. $2 \mathrm{~km}$ a.s.l. The most recent uplift event also resulted in re-exposure of a pre-basalt erosion surface with etch characteristics, resulting from deep weathering in a warm, humid climate. Towards the north (Germania Land and Store Koldewey) the LPS reaches c. $600 \mathrm{~m}$ a.s.I., only.

The relative denudation chronology established here shows that the topography in North-East Greenland was not related to a break-up in the northeast Atlantic but developed much later. The denudation chronology for the elevated plateaus in North-East Greenland is similar to that previously established for southern East Greenland and central West Greenland. In these areas, absolute dating from AFTA documented three events of uplift in the late Eocene, late Miocene and early Pliocene that led to the formation of the UPS, the LPS and finally to their rise to their present-day elevation.

The dramatic change of the East Greenland topography since Miocene times was an important precondition for the establishment of the Greenland ice sheet, and the formation of the LPS by the fluvial system shows that full glacial conditions were likely only established after uplift of the LPS in the early Pliocene. In summary, the UPS and the LPS provide a visual manifestation of multiple episodes of tectonic uplift that affected NorthEast Greenland in late Neogene times.

\section{Acknowledgements}

This study benefited from support and interest from many researchers at GEUS, in particular, Asger Ken Pedersen, James A. Chalmers, Lotte Melchior Larsen, Stuart Watt and Troels Nielsen. Paul F. Green commented an early draft of the manuscript. We thank reviewers Adrian Hall and Jean-Pierre Peulvast for constructive comments, which significantly improved the paper. ASTER GDEM is a product of METI and NASA.

\section{Additional information}

Funding statement

This work was funded by a consortium of oil companies and GEUS.

Competing interests

The authors declare no competing interests.

Author contributions

JMB: Conceptualisation, Investigation, Methodology, Writing - original draft, Writing - review \& editing. PJ: Investigation, Writing - review \& editing.

\section{Additional files}

Three supplementary files are available alongside this article online, in the GEUS Bulletin data repository: https://doi.org/10.22008/FK2/TMDFP9

\section{References}

Ager, D.V. 1973: The nature of the stratigraphic record, $151 \mathrm{pp}$. Chichester: John Wiley \& Sons. https://doi.org/10.1002/gj.3350290115

Ahlmann, H.W. 1919: Geomorphological studies in Norway. Geografiska Annaler 1, 3-320. https://doi.org/10.1080/20014422.1919.11880647

Ahlmann, H.W. 1941: Studies in North-East Greenland 1939-1940, Part I \& II. Geografiska Annaler 23, 145-209. https://doi.org/10.1080/ 20014422.1941.11880699

Ahnert, F. 1998: Introduction to Geomorphology, 352 pp. London: Arnold. Amante, C. \& Eakins, B.W. 2009: ETOPO1 1 arc-minute global relief model: procedures, data sources and analysis. National Oceanic and Atmospheric Administration, NOAA Technical Memorandum NESDIS NGDC-24. 19 pp. Colorado: Boulder.

André, M. 2001: Tors et roches moutonnées en Laponie suédoise: antagonisme oufiliation? Géographie Physique et Quaternaire 55(3), 229-242. https://doi.org/10.7202/006852ar

André, M. 2002: Rates of postglacial rock weathering on glacially scoured outcrops (Abisko-Riksgränsen area, 68 $\mathrm{N}$ ). Geografiska Annaler: Series A, Physical Geography 84, 139-150. https://doi. org/10.1111/j.0435-3676.2002.00168.x

Bate, K.J. 1997: Interpretation of the basal section of well Kangâmiut-1, offshore southern West Greenland, 28 pp. Geological Survey of Greenland, Report 1997/76. Unpublished report, Geological Survey of Greenland.

Baulig, H. 1935: The changing sea level. Transactions (Institute of British Geographers) 3, 46 pp. https://doi.org/10.2307/620990

Bengaard, H.J., Henriksen, N. \& Jepsen, H.F. 2007: Geological maps of North and North-East Greenland, 1:250 000. Copenhagen: Geological Survey of Denmark and Greenland.

Benito-Calvo, A. \& Pérez-González, A. 2007: Erosion surfaces and Neogene landscape evolution in the NE Duero Basin (north-central 
Spain). Geomorphology 88, 226-241. https://doi.org/10.1016/j. geomorph.2006.11.005

Bennike, O., Abrahamsen, N., Bak, M., Israelson, C., Konradi, P., Matthiessen, J. \& Witkowski, A. 2002: A multi-proxy study of Pliocene sediments from lle de France, North-East Greenland. Palaeogeography, Palaeoclimatology, Palaeoecology 186, 1-23. https://doi.org/10.1016/s0031-0182(02)00439-x

Bennike, O., Knudsen, K.L., Abrahamsen, N., Böcher, J., Cremer, H. \& Wagner, B. 2010: Early Pleistocene sediments on Store Koldewey, Northeast Greenland. Boreas 39, 603-619. https://doi. org/10.1111/j.1502-3885.2010.00147.x

Bernard, T., Knudsen, K.L., Abrahamsen, N., Böcher, J., Cremer, H. \& Wagner, B. 2016: Evidence for Eocene-Oligocene glaciation in the landscape of the East Greenland margin. Geology 44, 895-898. https://doi.org/10.1130/g38248.1

Birkelund, T. \& Perch-Nielsen, K. 1976: Late Palaeozoic-Mesozoic evolution of central East Greenland. In: Escher, A. \& Watt, W.S. (eds): Geology of Greenland, 305-339. Copenhagen: Geological Survey of Greenland.

Bishop, P. 2007: Long-term landscape evolution: linking tectonics and surface processes. Earth Surface Processes and Landforms 32, 329-365. $h$ ttps://doi.org/10.1002/esp.1493

Biswas, S., Coutand, I., Grujic, D., Hager, C., Stöcket, D. \& Grasemann B. 2007: Exhumation and uplift of the Shillong plateau and its influence on the eastern Himalayas: new constraints from apatite and zircon (U-Th-[Sm])/He and apatite fission track analyses. Tectonics 26, TC6013. https://doi.org/10.1029/2007TC002125

Blischke, A., Stoker, M.S., Brandsdóttir, B., Hopper, J.R., Peron-Pinvidic, G., Ólavsdóttir, J. \& Japsen, P. 2019: The Jan Mayen microcontinent's Cenozoic stratigraphic succession and structural evolution within the NE-Atlantic. Marine and Petroleum Geology 103, 702-737. https://doi. org/10.1016/j.marpetgeo.2019.02.008

Bonow, J.M. 2004: Palaeosurfaces and palaeovalleys on North Atlantic previously glaciated passive margins - reference forms for conclusions on uplift and erosion. PhD thesis, Thesis in geography with emphasis on physical geography 30,17 pp. +4 articles. Sweden: Stockholm University.

Bonow, J.M. 2005: Re-exposed basement landforms in the Disko region West Greenland - disregarded data for estimation of glacial erosion and uplift modelling. Geomorphology 72, 106-127. https://doi. org/10.1016/j.geomorph.2005.05.006

Bonow, J.M., Japsen, P. \& Nielsen, T.F.D. 2014: High-level landscapes along the margin of southern East Greenland - a record of tectonic uplift and incision after break up in the NE Atlantic. Global and Planetary Change 116, 10-29. https://doi.org/10.1016/j.g/oplacha.2014.01.010

Bonow, J.M., Japsen, P., Green, P.F., Cobbold, P.R., Pedreira, A.J., Lilletveit, R. \& Chiossi, D. 2009: Post-rift landscape development of north-east Brazil. Geological Survey of Denmark and Greenland Bulletin, 17 81-84. https://doi.org/10.34194/geusb.v17.5020

Bonow, J.M., Japsen, P., Green, P.F., Wilson, R.W., Chalmers, J.A., Klint, K.E.S., van Gool, J.A.M., Lidmar-Bergström, K. \& Pedersen, A.K. 2007a: A multidisciplinary study of Phanerozoic landscape development in West Greenland. Geological Survey of Denmark and Greenland Bulletin 13, 33-36. https://doi.org/10.34194/geusb.v13.4970

Bonow, J.M., Lidmar-Bergström, K., Japsen, P., Chalmers, J.A., Green, P.F. 2007b: Elevated erosion surfaces in central West Greenland and Southern Norway: their significance in integrated studies of passive margin development. Norwegian Journal of Geology 87(1-2), 197-206.

Bonow, J.M., Japsen, P., Lidmar-Bergström, K., Chalmers, J.A. \& Pedersen, A.K. 2006a: Cenozoic uplift of Nuussuaq and Disko, West Greenland - elevated erosion surfaces as uplift markers of a passive margin. Geomorphology 80, 325-337. https://doi.org/10.1016/j. geomorph.2006.03.006

Bonow, J.M., Lidmar-Bergström, K. \& Japsen, P. 2006b: Palaeosurfaces in central West Greenland as reference for identification of tectonic movements and estimation of erosion. Global and Planetary Change 50, 161-183. https://doi.org/10.1016/j.g/oplacha.2005.12.011

Bonow, J.M., Lidmar-Bergström, K. \& Näslund, J.O. 2003: Palaeosurfaces and major valleys in the area of the Kjølen Mountains, southern Norway - consequences of uplift and climatic change. Norsk
Geografisk Tidsskrift/Norwegian Journal of Geography 57, 83-101. https://doi.org/10.1080/00291950310001360

Braun, J. 2018: A review of numerical modelling studies of passive margin escarpments leading to a new analytical expression for the rate of escarpment migration velocity. Gondwana Research 53, 209-224. https://doi.org/10.1016/j.gr.2017.04.012

Brooks, C.K. 1985: Vertical crustal movements in the Tertiary of central East Greenland: a continental margin at a hot-spot. Zeitschrift für Geomorphologie 54, 101-117.

Brooks, C.K. 2011: The East Greenland rifted volcanic margin. Geological Survey of Denmark and Greenland Bulletin 24, 96 pp. https://doi. org/10.34194/geusb.v24.4732

Brunsden, D. 1993: The persistence of landforms. Zeitschrift für Geomorphologie Supplementband 93, 13-28.

Butt, F.A., Elverhøi, A., Forsberg, C.F. \& Solheim, A. 2001: Evolution of the Scoresby Sund fan, central East Greenland - evidence from ODP site 987. Norwegian Journal of Geology 81(1), 3-15.

Calvet, M., Gunnell, Y. \& Farines, B. 2015: Flat-topped mountain ranges: their global distribution and value for understanding the evolution of mountain topography. Geomorphology 241, 255-291. https://doi. org/10.1016/j.geomorph.2015.04.015

Chalmers, J.A., Green, P., Japsen, P. \& Rasmussen, E.S. 2010: The Scandinavian mountains have not persisted since the Caledonian orogeny. A comment on Nielsen et al. (2009a). Journal of Geodynamics 50, 94-101. https://doi.org/10.1016/j.jog.2010.02.001

Channell, J., Smelror, M., Jansen, E., Higgins, S.M., Lehman, B., Eidvin, T. \& Solheim, A. 1999: Age models for glacial fan deposits off East Greenland and Svalbard (sites 986 and 987). In: Jansen, E. et al. (eds): Proceedings Ocean Drilling Program, Scientific Results 162, 149-166. College Station, TX: Ocean Drilling Program. https://doi.org/10.2973/ odp.proc.sr.162.008.1999

Coltorti, M., Dramis, F. \& Ollier, C.D. 2007: Planation surfaces in Northern Ethiopia. Geomorphology 89, 287-296. https://doi.org/10.1016/j. geomorph.2006.12.007

Cook, S.J., Swift, D.A., Kirkbride, M.P., Knight, P.G. \& Waller, R.I. 2020: The empirical basis for modelling glacial erosion rates. Nature Communications 11, 759 pp. https://doi.org/10.1038/ s41467-020-14583-8

da Silva, B.V., Hackspacher, P.C., Ribeiro, M.C.S., Glasmacher, U.A., Gonçalves, A.O., Doranti-Tiritan, C., de Godoy, D.F. \& Constantino, R.R. 2018: Evolution of the Southwestern Angolan Margin: episodic burial and exhumation is more realistic than long-term denudation. International Journal of Earth Sciences 108, 1-25. https://doi. org/10.1007/s00531-018-1644-4

Davis, W.M. 1899: The geographical cycle. Geographical Journal 14(A), 481-504. https://doi.org/10.2307/1774538

Døssing, A., Japsen, P., Watts, A.B., Nielsen, T., Jokat, W., Thybo, H. \& Dahl-Jensen, T. 2016: Miocene uplift of the NE Greenland margin linked to plate tectonics: seismic evidence from the Greenland Fracture Zone. NE Atlantic. Tectonics 35, 257-282. https://doi. org/10.1002/2015tc004079

Dowsett, H.J., Robinson, M.M., Haywood, A.M., Salzmann, U., Hill, D.J, Sohl, L., Chandler, M., Williams, M., Foley, K.M. \& Stoll, D.K. 2010: The PRISMD3D paleo-environmental reconstruction. Stratigraphy $\mathbf{7}$, 123-139.

Ebert, K. \& Hättestrand, C. 2010: The impact of Quaternary glaciations on inselbergs in northern Sweden. Geomorphology 115, 56-66. https:// doi.org/10.1016/j.geomorph.2009.09.030

Egholm, D.L., Jansen, J.D., Brædstrup, C.F., Pedersen, V.K., Andersen, J.L., Ugelvig, S.V., Larsen, N.K. \& Knudsen, M.F. 2017: Formation of plateau landscapes on glaciated continental margins. Nature Geoscience 10, 592-597. https://doi.org/10.1038/ngeo2980

Eldrett, J.S., Greenwood, D.R., Harding, I.C. \& Huber, M. 2009: Increased seasonality through the Eocene to Oligocene transition in northern high latitudes. Nature 459, 969-973. https://doi.org/10.1038/nature08069

Eldrett, J.S., Harding, I.C., Wilson, P.A., Butler, E. \& Roberts, A.P. 2007: Continental ice in Greenland during the Eocene and Oligocene. Nature 446, 176-179. https://doi.org/10.1038/nature05591

Fairbridge, R.W. \& Finkl, J.R. 1980: Cratonic erosional unconformities and peneplains. Journal of Geology 88, 69-86. https://doi.org/10.1086/628474 
Feyling-Hanssen, R.W., Funder, S. \& Petersen, K.S. 1983: The Lodin Elv formation: a Plio-Pleistocene occurrence in Greenland. Bulletin of the Geological Society of Denmark 31, 81-106.

Fjellanger, J. \& Etzelmüller, B. 2003: Stepped palaeosurfaces in southern Norway - interpretation of DEM-derived topographic profiles. Norsk Geografisk Tidsskrift/Norwegian Journal of Geography 57, 102-110. https://doi.org/10.1080/00291950310001388

Freire, F., Gyllencreutz, R., Greenwood, S.L., Mayer, L., Egilsson, A., Thorsteinsson, T. \& Jakobsson, M. 2015: High resolution mapping of offshore and onshore glaciogenic features in metamorphic bedrock terrain, Melville Bay, northwestern Greenland. Geomorphology 250, 29-40. https://doi.org/10.1016/j.geomorph.2015.08.011

Fu, P., Stroeven, A.P., Harbor, J.M., Heyman, J., Hättestrand, C. \& Caffee, M.W. 2019: Ice cap erosion patterns from bedrock 10Be and 26Al, southeastern Tibetan Plateau. Earth Surfaces Processes and Landforms 44, 918-932. https://doi.org/10.1002/esp.4544

Funder, S., Bennike, O., Böcher, J., Israelson, C., Petersen, K.S. \& Símonason, L.A. 2001: Late Pliocene Greenland - the Kap København formation in North Greenland. Bulletin of the Geological Society of Denmark 48, 117-134.

Gaina, C., Gernigon, L. \& Ball, P. 2009: Paleocene - recent plate boundaries in the NE Atlantic and the formation of the Jan Mayen micro continent. Journal of the Geological Society London 166, 601-616. https:// doi.org/10.1144/0016-76492008-112

Gaina, C., Nasuti, A., Kimbell, G.S. \& Blischke, A. 2017: Break-up and seafloor spreading domains in the NE Atlantic. Geological Society, London, Special Publications 447, 393-417. https://doi.org/10.1144/SP447.12

Gallagher, K., Brown, R. \& Johnson, C. 1998: Fission track analysis and its applications to geological problems. Annual Review of Earth and Planetary Sciences 26, 519-572. https://doi.org/10.1146/annurev. earth.26.1.519

GEUS. 2007: Topographic maps of North and North-East Greenland 1: 250 000. Copenhagen: Geological Survey of Denmark and Greenland.

Gilchrist, A.R. \& Summerfield, M.A. 1990: Differential denudation and flexural isostasy in formation of rifted-margins upwarps. Nature 346, 739-742. https://doi.org/10.1038/346739a0

Glasser, N.F. \& Warren, C.R. 1990: Medium scale landforms of glacial erosion in South Greenland: process and form. Geografiska Annaler: Series A, Physical Geography 72, 211-215. https://doi.org/10.1080/043 53676.1990.11880317

GLOBE Task Team et al. 1999: The global land one-kilometre base elevation (GLOBE). Digital Elevation Model, Version 1.0. National Oceanic and Atmospheric Administration. http://www.ngdc.noaa.gov/mgg/topo/ globe.html (accessed August 2019)

Godard, A., Simon-Coincon, R. \& Lagasquie, J.-J. 2001: Planation surfaces in basement terrains. In: Godard, A. et al. (eds): Basement regions, 9-34. Berlin: Springer.

Green, P.F., Duddy, I.R., Japsen, P., Bonow, J.M. \& Malan, J.A. 2017: Postbreakup burial and exhumation of the southern margin of Africa. Basin Research 29, 96-127. https://doi.org/10.1111/bre.12167

Green, P.F., Japsen, P., Chalmers, J.A., Bonow, J.M. \& Duddy, I.R. 2018: Post-breakup burial and exhumation of passive continental margins: seven propositions to inform geodynamic models. Gondwana Research 53, 58-81. https://doi.org/10.1016/j.gr.2017.03.007

Green, P.F., Lidmar-Bergström, K., Japsen, P., Bonow, J.M. \& Chalmers, J.A. 2013: Stratigraphic landscape analysis, thermochronology and the episodic development of elevated passive continental margins. Geological Survey of Denmark and Greenland Bulletin 30, 150 pp. https://doi.org/10.34194/geusb.v30.4673

Guillocheau, F., Simon, B., Baby, G., Bessin, P., Robin, C. \& Dauteuil, O. 2018: Planation surfaces as a record of mantle dynamics: the case example of Africa. Gondwana Research 53, 82-98. https://doi. org/10.1016/j.gr.2017.05.015

Haider, V.L., Dunkl, I., von Eynatten, H., Ding, L., Frei, D. \& Zhang, L. 2013 : Cretaceous to Cenozoic evolution of the northern Lhasa Terrane and the early Paleogene development of peneplains at Nam Co, Tibetan Plateau. Journal of Asian Earth Sciences 70-71, 79-98. https://doi. org/10.1016/j.jseaes.2013.03.005

Håkansson, L., Graf, A., Strasky, S., Ivy-ochs, S., Kubik, P.W., Hjort, C. \& Schlüchter, C. 2007: Cosmogenic 10Be-ages from the Store Koldewey
Island. NEGreenland,GeografiskaAnnaler:SeriesA,PhysicalGeography 89, 195-202. https://doi.org/10.1111/j.1468-0459.2007.00318.x

Hall, A.M. \& Kleman, J. 2014: Glacial and periglacial buzzsaws: fitting mechanisms to metaphors. Quaternary Research 81, 189-192. https://doi.org/10.1016/j.yqres.2013.10.007

Hall, A.M., Ebert, K., Kleman, J., Nesje, A. \& Ottesen, D. 2013a: Selective glacial erosion on the Norwegian passive margin. Geology 41, 1203-1206. https://doi.org/10.1130/G34806.1

Hall, A.M., Ebert, K. \& Hättestrand, C. 2013b: Pre-glacial landform inheritance in a glaciated shield landscape. Geografiska Annaler: Series A, Physical Geography 95, 33-49. https://doi. org/10.1111/j.1468-0459.2012.00477.x

Hall, A.M., Krabbendam, M., van Boeckel, M., Goodfellow, B.W., Hättestrand, C., Heyman, J., Palamakumbura, R.N., Stroeven, A.P. \& Näslund, J.-O. 2020: Glacial ripping: geomorphological evidence from Sweden for a new process of glacial erosion. Geografiska Annaler: Series A, Physical Geography 102. https://doi.org/10.1080/04353676.2 020.1774244

Haller, J. 1971: Geology of the East Greenland Caledonides, 413 pp. London: Interscience Publishers.

Hamann, N.E., Whittaker, R.C. \& Stemmerik, L. 2005: Geological development of the Northeast Greenland Shelf. Geological Society, London, Petroleum Geology Conference Series 6, 887-902. https:// doi.org/10.1144/0060887

Henriksen, N. 2008: Geological history of Greenland: four billion years of earth evolution, 272 pp. Copenhagen: Geological Survey of Denmark and Greenland.

Henriksen, N., Higgins, A.K., Gilotti, J.A. \& Smith, M.P. 2008: Introduction - the Caledonides of Greenland. In: Higgins, A.K. et al. (eds): The Greenland Caledonides: evolution of the Northeast Margin of Laurentia. Geological Society of America Memoir 202, v-xv. https://doi. org/10.1130/2008.1202(00)

Henriksen, N., Higgins, A.K., Kalsbeek, F. \& Pulvertaft, T.C.R. 2009: Greenland from Archean to Quaternary: descriptive text to the 1995 Geological map of Greenland. Geological Survey of Denmark and Greenland Bulletin 18, 126 pp. https://doi.org/10.34194/ggub. v185.5197

Hetzel, R., Dunkl, I., Haider, V., Strobl, M., von Eynatten, H., Ding, L. \& Frei, D. 2011: Peneplain formation in southern Tibet predates the India-Asia collision and plateau uplift. Geology 39, 983-986. https:// doi.org/10.1130/G32069.1

Higgins, A.K., Gilotti, J.A. \& Smith, M.P. (eds). 2008: The Greenland Caledonides: evolution of the Northeast Margin of Laurentia. Geological Society of America Memoir 202, 368 pp. https://doi. org/10.1130/MEM202

Jansen, E., Raymo, M. \& Blum, P. 1996: Ocean drilling program, Leg 162 preliminary report, North Atlantic Arctic Gateways II, 345-387. College Station, Texas A and M University, TX. https://doi.org/10.2973/odp. pr.162.1995

Japsen, P. \& Chalmers, J.A. 2000: Neogene uplift and tectonics around the North Atlantic: overview. Global and Planetary Change 24, 165-173. https://doi.org/10.1016/s0921-8181(00)00006-0

Japsen, P., Bonow, J.M., Green, P.F., Chalmers, J.A. \& Lidmar-Bergström, K. 2006: Elevated, passive continental margins: long-term highs or Neogene uplifts? New evidence from West Greenland. Earth and Planetary Science Letters 248, 330-339. https://doi.org/10.1016/j. epsl.2006.05.036

Japsen, P., Bonow, J.M., Green, P.F., Chalmers, J.A. \& Lidmar-Bergström, K. 2009: Formation, uplift and destruction of planation surfaces at passive continental margins. Earth Surface Processes and Landforms 34, 683-699. https://doi.org/10.1002/esp.1766

Japsen, P., Chalmers, J.A., Green, P.F. \& Bonow, J.M. 2012a: Elevated, passive continental margins: not rift shoulders, but expressions of episodic, post-rift burial and exhumation. Global and Planetary Change 90-91, 73-86. https://doi.org/10.1016/j.gloplacha.2011.05.004

Japsen, P., Bonow, J.M., Green, P.F., Cobbold, P.R., Chiossi, D., Lilletveit, R., Magnavita, L.P. \& Pedreira, A.J. 2012b: Episodic burial and exhumation history of NE Brazil after opening of the South Atlantic. Geological Society of America Bulletin 124, 800-816. https://doi.org/10.1130/ b30515.1 
Japsen, P., Green, P.F. \& Chalmers, J.A. 2013: The mountains of NorthEast Greenland are not remnants of the Caledonian topography. A comment on Pedersen et al. (2012): Tectonophysics 530-531, 318-330. Tectonophysics 589, 234-238. https://doi.org/10.1016/j. tecto.2012.07.026

Japsen, P., Green, P.F., Bonow, J.M., Bjerager, M. \& Hopper, J.R. In press: Thermo-tectonic history of North-East Greenland. GEUS Bulletin 45.

Japsen, P., Green, P.F., Bonow, J.M., Nielsen, T.F.D. \& Chalmers, J.A. 2014: From volcanic plains to glaciated peaks: burial and exhumation history of southern East Greenland after opening of the NE Atlantic. Global and Planetary Change 116, 91-114. https://doi.org/10.1016/j. gloplacha.2014.01.012

Japsen, P., Green, P.F., Chalmers, J.A., Duddy, I. \& Bonow, J.M. 2019: Elevated passive continental margins: numerical modelling vs observations: a comment on Braun (2018). Gondwana Research 65, 172-173. https://doi.org/10.1016/j.gr.2018.10.004

Jessen, O. 1943: Die Randschwellen der Kontinente. Petermanns Geographische Mitteilungen 241, 205 pp. Gotha: Justus Perthes.

Johansson, M., Olvmo, M. \& Lidmar-Bergström, K. 2001: Inherited landforms and glacial impact of different palaeosurfaces in southwest Sweden. Geografiska Annaler, Series A: Physical Geography 83A, 67-89. https://doi.org/10.1111/1468-0459.00145

Jolley, D.W. \& Whitham, A.G. 2004: A stratigraphical and palaeoenvironmental analysis of the sub-basaltic Palaeogene sediments of East Greenland. Petroleum Geoscience 10, 53-60. https://doi. org/10.1144/1354-079302-511

King, L.C. 1967: The morphology of the earth, 2nd edition, 726 pp. Edinburgh: Oliver \& Boyd. https://doi.org/10.1180/minmag.1967.036. 279.23

Kleman, J. \& Hättestrand, C. 1999: Frozen-bed Fennoscandian and Laurentide ice sheets during the last glacial maximum. Nature 402, 63-66. https://doi.org/10.1038/47005

Kleman, J. 1994: Preservation of landforms under ice sheets and ice caps. Geomorphology 9, 19-32. https://doi.org/10.1016/0169-555X (94)90028-0

Kleman, J. 2008: Geomorphology - where glaciers cut deep. Nature Geoscience 1, 343-344. https://doi.org/10.1038/ngeo210

Kleman, J., Stroeven, A.P. \& Lundqvist, J. 2008: Patterns of Quaternary ice sheet erosion and deposition in Fennoscandia and a theoretical framework for explanation. Geomorphology 97, 73-90. https://doi. org/10.1016/j.geomorph.2007.02.049

Krabbendam, M. \& Bradwell, T. 2014: Quaternary evolution of glaciated gneiss terrains: pre-glacial weathering vs. glacial erosion. Quaternary Science Review 95, 20-42. https://doi.org/10.1016/j. quascirev.2014.03.013

Larsen, H.C., Saunders, A.D., Clift, P.D. \& the Shipboard Scientific Party. 1994a: 13. Summary and principal results. In: Larsen, H.C. \& Stewart, S.K. (eds): Proceedings of the Ocean Drilling Program, Initial Reports 152, 279-292. College Station, Ocean Drilling Program, TX. https://doi.org/10.2973/odp.proc.ir.152.113.1994

Larsen, H.C., Saunders, A.D., Clift, P.D., Beget, J., Wei, W. \& Spezzaferri, S. 1994b: Seven million years of glaciation in Greenland. Science 264, 952-955. https://doi.org/10.1126/science.264.5161.952

Larsen, L.M., Pedersen, A.K., Sørensen, E.V., Watt, W.S. \& Duncan, R.A. 2013: Stratigraphy and age of the Eocene Igtertivâ formation basalts, alkaline pebbles and sediments of the Kap Dalton Group in the graben at Kap Dalton, East Greenland. Bulletin of the Geological Society of Denmark 61, 1-18.

Larsen, L.M., Pedersen, A.K., Tegner, C. \& Duncan, R.A. 2014: Eocene to Miocene igneous activity in NE Greenland: northward younging of magmatism along the East Greenland margin. Journal of the Geological Society of London 171, 539-553. https://doi.org/10.1144/ jgs2013-118

Larsen, L.M., Watt, W.S. \& Watt, M. 1989: Geology and petrology of the lower tertiary plateau basalts of the Scoresby Sund region, East Greenland. Grønlands Geologiske Undersøgelse Bulletin 157, 164 pp.

Larsen, P.-H. \& Bengaard, H.-J. 1991: Devonian basin initiation in East Greenland: a result of sinistral wrench faulting and Caledonian extensional collapse. Journal of the Geological Society of London 148, 355-368. https://doi.org/10.1144/gsjgs.148.2.0355
Larsen, P.H. 1988: Relay structures in a Lower Permian basementinvolved extension system, East Greenland. Journal of Structural Geology 10, 3-8. https://doi.org/10.1016/0191-8141(88)90122-8

Larsen, R.B. \& Tegner, C. 2006: Pressure conditions for the solidification of the Skaergaard intrusion: eruption of East Greenland flood basalts in less than 300,000 years. Lithos 92, 181-197. https://doi. org/10.1016/j.lithos.2006.03.032

Lassen, A. \& Thybo, H. 2012: Neoproterozoic and Palaeozoic evolution of SW Scandinavia based on integrated seismic interpretation. Precambrian Research 204-205, 75-104. https://doi.org/10.1016/j. precamres.2012.01.008

Li, J.J., Fang, X.M., Song, C.H., Pan, B.T., Ma, Y.Z. \& Yan, M.D. 2014: Late Miocene-Quaternary rapid stepwise uplift of the NE Tibetan Plateau and its effects on climatic and environmental changes. Quaternary Research 81, 400-423. https://doi.org/10.1016/j.yqres.2014.01.002

Lidmar-Bergström, K. 1982: Pre-Quaternary geomorphological evolution in southern Fennoscandia. Sveriges Geologiska Undersökning, Ser. C, No. 785, 1-202.

Lidmar-Bergström, K. 1988: Denudation surfaces of a shield area in south Sweden. Geografiska Annaler Series A, Physical Geography 70A, 337-350. https://doi.org/10.2307/521267

Lidmar-Bergström, K. 1989: Exhumed Cretaceous landforms in south Sweden. Zeitschrift für Geomorphologie, Neue Folge, Supplementband 72, 21-40.

Lidmar-Bergström, K. 1997: A long-term perspective on glacial erosion. Earth Surface Processes and Landforms 22, 297-306. https://doi. org/10.1002/(sici)1096-9837(199703)22:3<297::aid-esp758>3.0.co;2-r

Lidmar-Bergström, K., Bonow, J.M. \& Japsen, P. 2013: Stratigraphic landscape analysis and geomorphological paradigms: Scandinavia as an example of Phanerozoic uplift and subsidence. Global and Planetary Change 100, 153-171. https://doi.org/10.1016/j.gloplacha.2012.10.015

Lidmar-Bergström, K., Ollier, C.D. \& Sulebak, J. 2000: Landforms and uplift history of southern Norway. Global and Planetary Change 24, 211-231. https://doi.org/10.1016/s0921-8181(00)00009-6

Lidmar-Bergström, K., Olvmo, O. \& Bonow, J.M. 2017: The South Swedish Dome: a key structure for identification of peneplains and conclusions on Phanerozoic tectonics of an ancient shield. Journal of the Geological Society of Sweden (GFF) 139, 244-259. https://doi.org/10.10 80/11035897.2017.1364293

Lindström, E. 1988: Are roches moutonnées mainly preglacial forms? Geografiska Annaler: Series A, Physical Geography 70A, 323-331. https://doi.org/10.1080/04353676.1988.11880263

Liu, F., Gao, H., Pan, B., Li, Z. \& Su, H. 2019: Quantitative analysis of planation surfaces of the upper Yangtze River in the Sichuan-Yunnan Region, Southwest China. Frontier of Earth Science 13, 55-74. https:// doi-org.ezproxy.its.uu.se/10.1007/s11707-018-0707-y

Ma, Z. et al. 2020: Landscape evolution of the Dabanshan planation surface: implications for the uplift of the eastern tip of the Qilian Mountains since the Late Miocene. Geomorphology 356, 107091. https://doi.org/10.1016/j.geomorph.2020.107091

Mathiesen, A., Bidstrup, T. \& Christiansen, F.G. 2000: Denudation and uplift history of the Jameson Land basin, East Greenland - constrained from maturity and apatite fission data. Global and Planetary Change 24, 275-301. https://doi.org/10.1016/s0921-8181(00)00013-8

Medvedev, S., Souche, A. \& Haartz, E.H. 2013: Influence of ice sheet and glacial erosion on passive margins of Greenland. Geomorphology 193, 36-46. https://doi.org/10.1016/j.geomorph.2013.03.029

Migoń, P. \& Lidmar-Bergström, K. 2001: Weathering mantles and their significance for geomorphological evolution of central and northern Europe since the Mesozoic. Earth-Science Reviews 56, 285-324. https://doi.org/10.1016/S0012-8252(01)00068-X

Mudelsee, M. \& Raymo, M.E. 2005: Slow dynamics of the Northern Hemisphere glaciation. Paleoceanography 20, PA4022. https://doi. org/10.1029/2005PA001153

Neuhoff, P.S., Watt, W.S., Bird, D.K. \& Pedersen, A.K. 1997: Timing and structural relations of regional zeolite zones in basalts of the East Greenland continental margin. Geology 25, 803-806. https://doi.org/ 10.1130/0091-7613(1997)025<0803:tasror>2.3.co;2

Nielsen, S.B. et al. 2009: The evolution of western Scandinavian topography: a review of Neogene uplift versus the ICE 
(isostasy-climate-erosion) hypothesis. Journal of Geodynamics 47, 72-95. https://doi.org/10.1016/j.jog.2008.09.001

Nielsen, T.F.D., Soper, N.J., Brooks, C.K., Faller, A.M., Higgins, A.K. \& Matthews, D.W. 1981: The pre-basaltic sediments and the Lower Basalts at Kangerdlugssuaq, East Greenland: their stratigraphy, lithology, palaeomagnetism and petrology. Meddelelser om Grønland Geoscience 6, 1-25.

Nøhr-Hansen, H., Nielsen, L.H., Sheldon, E., Hovikovski, J. \& Alsen, P. 2011: Palaeogene deposits in North-East Greenland. Geological Survey of Denmark and Greenland Bulletin 23, 61-64. https://doi. org/10.34194/geusb.v23.4867

Ollier, C.D. \& Pain, C.F. 1997: Equating the basal unconformity with the palaeoplain: a model for passive margins. Geomorphology 19, 1-15. https://doi.org/10.1016/s0169-555x(96)00048-7

Parsons, A. et al. 2017: Structural evolution and basin architecture of the Traill $\varnothing$ region, NE Greenland: a record of polyphase rifting of the East Greenland continental margin. Geosphere 13, 733-770. https:// doi.org/10.1130/ges01382.1

Pedersen, A.K., Watt, M., Watt, W.S. \& Larsen, L.M. 1997: Structure and stratigraphy of the Early Tertiary basalts of the Blosseville Kyst, East Greenland. Journal of the Geological Society of London 154, 565-570. https://doi.org/10.1144/gsjgs.154.3.0565

Pedersen, V.K. \& Egholm, D.L. 2013: Glaciations in response to climate variations preconditioned by evolving topography. Nature 493, 206-210. https://doi.org/10.1038/nature11786

Pedersen, V.K., Larsen, N.K. \& Egholm, D.L. 2019: The timing of fjord formation and early glaciations in North and Northeast Greenland. Geology 47, 682-686. https://doi.org/10.1130/g46064.1

Pedersen, V.K., Nielsen, S.B. \& Gallagher, K. 2012: The post-orogenic evolution of the Northeast Greenland Caledonides constrained from apatite fission track analysis and inverse geodynamic modelling. Tectonophysics 530-531, 318-330. https://doi.org/10.1016/j. tecto.2012.01.018

Penck, W. 1924: Die morphologische analyse. Geographische Abhandlungen. 2. Reihe, Hefte 3.XX u. 283 S. Stuttgart: Engelhorn.

Pérez, L.F., Nielsen, T., Knutz, P.C., Kuijpers, A. \& Damm, V. 2018: Largescale evolution of the central-east Greenland margin: new insights to the North Atlantic glaciation history. Global and Planetary Change 163, 141-157. https://doi.org/10.1016/j.g/oplacha.2017.12.010

Petersen, T.G. 2019: Seismic stratigraphy of the post-breakup succession offshore Northeast Greenland: links to margin uplift. Marine and Petroleum Geology 103, 422-437. https://doi.org/10.1016/j. marpetgeo.2019.03.007

Peulvast, J., Bonow, J.M., Japsen, P., Wilson, R.W. \& McCaffrey, K.J.W. 2011: Morphostructural patterns and landform generations in a glaciated passive margin: the Kobberminebugt-Qaqortoq region of South Greenland. Geodinamica Acta 24(1), 1-19. https://doi.org/10.3166/ ga.24.1-19

Peulvast, J.P. \& Bétard, F. 2015: Landforms and landscape evolution of the equatorial margin of northeast Brazil. Springer Earth System Sciences. Cham: Springer.

Peulvast, J.P. \& Claudino Sales, V. 2004: Stepped surfaces and palaeolandforms in the northern Brazilian «Nordeste»: constraints on models of morphotectonic evolution. Geomorphology 62, 89-122. https:// doi.org/10.1016/j.geomorph.2004.02.006

Peulvast, J.P. 1988: Pre-glacial landform evolution in two coastal high latitude mountains: Lofoten-Vesterålen (Norway) and Scoresby Sund area (Greenland). Geografiska Annaler Series A, Physical Geography 70A, 351-360. $h$ ttps://doi.org/10.2307/521268

Peulvast, J.P. 1991: Structural geomorphology and morphotectonic evolution of an uplifted rifted margin: the Scoresby Sund area, East Greenland. Zeitschrift für Geomorphologie Supplementband 82, 17-34.

Peulvast, J.P., Betard, F. \& Lageat, Y. 2009: Long-term landscape evolution and denudation rates in shield and platform areas: a morphostratigraphic approach. Géomorphologie: Relief, Processus, Environnement 15, 95-107. https://doi.org/10.4000/geomorphologie.7540

Pulvertaft, T.C.R. \& Larsen, J.G. 2002: Note on the sub-basalt surface in the hinterland of the Nuussuaq basin, central West Greenland. Geological Survey of Denmark and Greenland Report 2002/39, 15 pp.
Raymo, M., Grant, B., Horowitz, M. \& Rau, G. 1996: Mid-Pliocene warmth: stronger greenhouse and stronger conveyor. Marine Micropaleontology 27, 313-326. https://doi.org/10.1016/0377-8398(95) 00048-8

Reusch, H. 1901: Nogle bidrag till forstaaelsen af hvorledes Norges dale og fjelde er blevene til. Norges Geologiske Undersøgelse 32, 124-263.

Sarnthein, M., Bartoli, G., Prange, M., Schmittner, A., Schneider, B., Weinelt, M., Andersen, N. \& Garbe-Schönberg, D. 2009: Mid-Pliocene shifts in ocean overturning circulation and the onset of Quaternarystyle climates. Climate of the Past 5, 269-283. https://doi.org/10.5194/ cp-5-269-2009

Schaefer, J.M., Finkel, R.C., Balco, G., Alley, R.B., Caffee, M.W., Briner, J.P., Young, N.E., Gow, A.J. \& Schwartz, R. 2016: Greenland was nearly ice-free for extended periods during the Pleistocene. Nature 540, 252-255. https://doi.org/10.1038/nature20146

Shackleton, N.J., Imbrie, J. \& Pisias, N. 1988: The evolution of oceanic oxygen-isotope variability in the North Atlantic over the past three million years. Philosophical Transactions of the Royal Society of London. B: Biological Sciences 318, 679-688. https://doi.org/10.1098/ rstb.1988.0030

Simon-Coinçon, R., Thiry, M. \& Schmitt, J.-M. 1997: Variety and relationships of weathering features along the early Tertiary palaeosurface in the southwestern French Massif Central and the nearby Aquitaine Basin. Palaeogeography, Palaeoclimatology, Palaeoecology 129, 51-79. https://doi.org/10.1016/s0031-0182(96)00122-8

Small, E.E. \& Anderson, R.S. 1998: Pleistocene relief production in Laramide mountain ranges, Western United States. Geology 26, 123-126. https://doi.org/10.1130/0091-7613(1998)026<0123:prpilm>2. 3. $\mathrm{Co} 2$

Solgaard, A.M., Bonow, J.M., Langen, P., Japsen, P. \& Hvidberg, C. 2013: Mountain building and the initiation of the Greenland ice sheet. Palaeogeography Palaeoclimatology Palaeoecology 392, 161-176. https://doi.org/10.1016/j.palaeo.2013.09.019

Steer, P., Huismans, R.S., Valla, P.G., Gac, S. \& Herman, F. 2012: Bimodal Plio-Quaternary glacial erosion of fjords and low-relief surfaces in Scandinavia. Nature Geoscience 5, 635-639. https://doi.org/10.1038/ ngeo1549

Steinberger, B., Spakman, W., Japsen, P. \& Torsvik, T.H. 2015: The key role of global solid-Earth processes in preconditioning Greenland's glaciation since the Pliocene. Terra Nova 27, 1-8. https://doi.org/10.1111/ ter.12133

Stemmerik, L. 2000: Late Palaeozoic evolution of the North Atlantic margin of Pangea. Palaeogeography, Palaeoclimatology, Palaeoecology 161, 95-126. https://doi.org/10.1016/s0031-0182(00)00119-x

Stemmerik, L., Christiansen, F.G., Piasecki, S., Jordt, B., Marcussen, C. \& Nøhr-Hansen, H. 1993: Depositional history and petroleum geology of the Carboniferous to Cretaceous sediments in the northern part of East Greenland. In: Vorren, T.O. et al. (eds): Arctic geology and petroleum potential. Norwegian Petroleum Society Special Publications 2, 67-87. https://doi.org/10.1016/b978-0-444-88943-0.50009-5

Storey, M., Pedersen, A.K., Stecher, O., Bernstein, S., Larsen, H.C., Larsen, L.M., Baker, J.A. \& Duncan, R.A. 2004: Long-lived postbreakup magmatism along the East Greenland margin: evidence for shallow-mantle metasomatism by the Iceland plume. Geology 32, 173-176. https:// doi.org/10.1130/g19889.1

Sugden, D.E. 1974: Landscapes of glacial erosion in Greenland and their relationship to ice, topographic and bedrock conditions. Institute of British Geographers Special Publications 7, 177-195.

Sugden, D.E., Balco, G., Cowdery, S.G., Stone, J.O. \& Sass, L.C. 2005: Selective glacial erosion and weathering zones in the coastal mountains of Marie Byrd Land, Antarctica. Geomorphology 67, 317-334. https://doi.org/10.1016/j.geomorph.2004.10.007

Sugden, D.E., Glasser, N. \& Clapperton, C.M. 1992: Evolution of large roches moutonnées. Geografiska Annaler Series A, Physical Geography 74A, 253-264. https://doi.org/10.1080/04353676.1992. 11880368

Surlyk, F. \& Ineson, J. 2003: The Jurassic of Denmark and Greenland: key elements in the reconstruction of the North Atlantic Jurassic rift system. In: Ineson, J. \& Surlyk, F. (eds.): The Jurassic of Denmark and 
Greenland. Geological Survey of Denmark and Greenland Bulletin 1, 9-20. https://doi.org/10.34194/geusb.v1.4644

Surlyk, F. 1977: Mesozoic faulting in East Greenland. Geologie en Mijnbouw. Netherlands Journal of Geosciences 56, 311-327.

Surlyk, F. 1978: Jurassic basin evolution of East Greenland. Nature 274, 130-133. https://doi.org/10.1038/274130a0

Surlyk, F. 1990: Timing, style and sedimentary evolution of Late Palaeozoic - mesozoic extensional basins of East Greenland. In: Hardman, R.F.P. \& Brooks, J. (eds.): Tectonic events responsible for Britain's oil and gas reserves. Geological Society, London, Special Publications 55, 107-125. https://doi.org/10.1144/GSL.SP.1990.055.01.05

Surlyk, F. 2003: The Jurassic of East Greenland: a sedimentary record of thermal subsidence, onset and culmination of rifting. Geological Survey of Denmark and Greenland Bulletin 1, 659-722. https://doi. org/10.34194/geusb.v1.4674

Swift, D.A., Persano, C., Stuart, F.M., Gallagher, K. \& Whitham, A. 2008: A reassessment of the role of ice sheet glaciation in the long-term evolution of the East Greenland fjord region. Geomorphology 97, 109-125. https://doi.org/10.1016/j.geomorph.2007.02.048
Thiede, J., Winkler, A., Wolf-Welling, T., Eldholm, O., Myhre, A.M., Baumann, K.H., Henrich, R. \& Stein, R. 1998: Late Cenozoic history of the Polar North Atlantic: results from ocean drilling. Quaternary Science Reviews 17, 185-208. https://doi.org/10.1016/s0277-3791(97)00076-0

Vigran, J.O., Stemmerik, L. \& Piasecki, S. 1999: Stratigraphy and depositional evolution of the uppermost Devonian-Carboniferous (Tournaisian-Westphalian) non-marine deposits in north-east Greenland. Palynology 23, 115-152. https://doi.org/10.1080/019161 22.1999.9989525

Vischer, A. 1943: Die postdevonische Tektonik von Ostgrönland zwischen $74^{\circ}$ und $75^{\circ} \mathrm{N}$.Br. Kuhn $\varnothing$, Wollaston Forland, Clavering $\varnothing$ und angrenzende Gebiete. Meddelelser om Grønland 133, 194 pp.

Wager, L.R. \& Deer, W.A. 1939: Geological investigations in east Greenland. Part III. The petrology of the Skaergaard intrusion, Kangerdlugssuaq, East Greenland. Meddelelser om Grønland 105(4), 352 pp.

Willerslev, E. et al. 2007: Ancient biomolecules from deep ice cores reveal a forested southern Greenland. Science 317, 111-114. https://doi. org/10.1126/science. 1141758 